
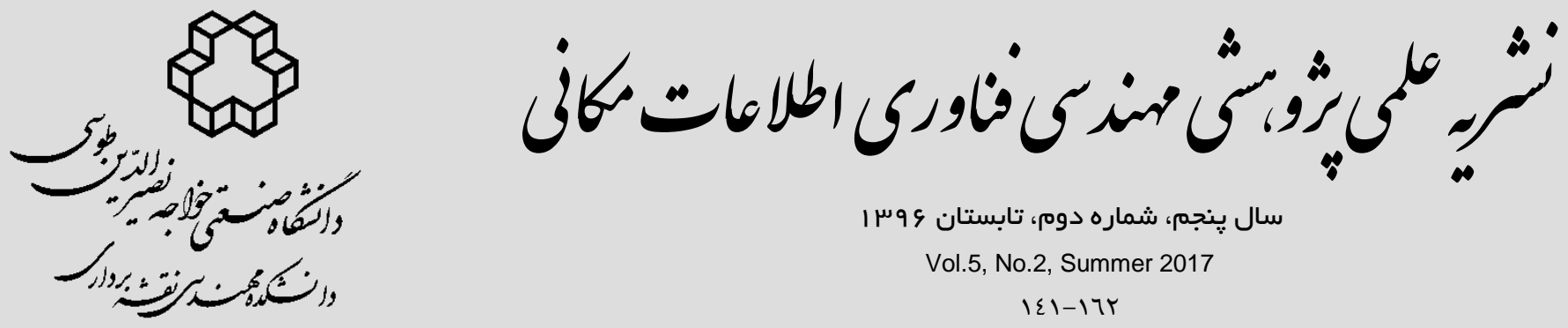

سال ينجم،، شماره دوهم، تابستان و وس

Vol.5, No.2, Summer 2017

IEI-ITr

شاخص كذارى موقعيت جارى و حَشته اشياء متحرك درمجموعه دادههاى بزرتى مقياس

محمدرضا عباسى فرد'، حسن نادرى "r"

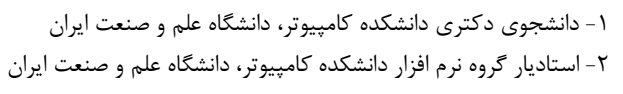

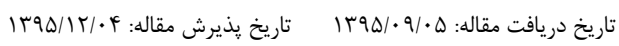

جكيده

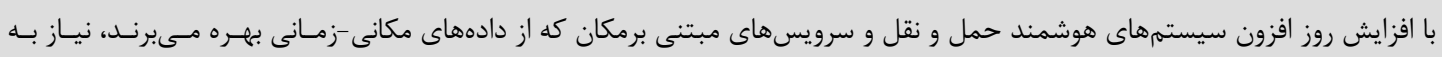

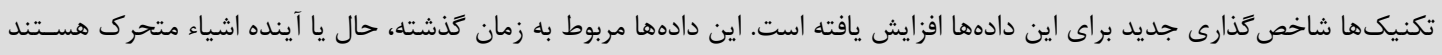

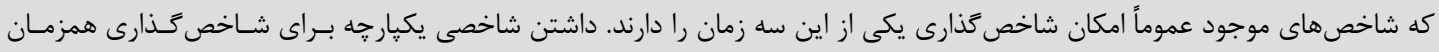

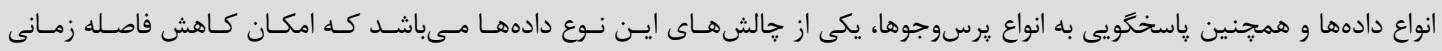

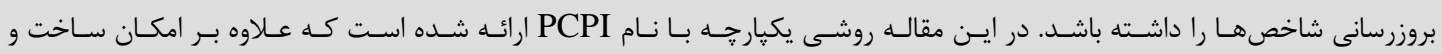

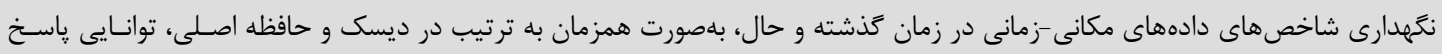

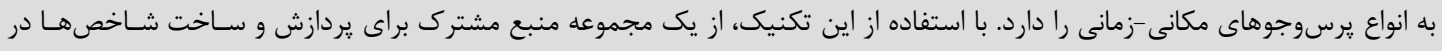

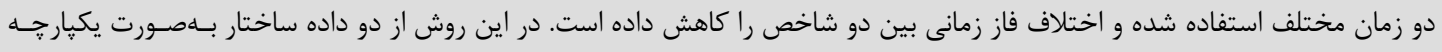

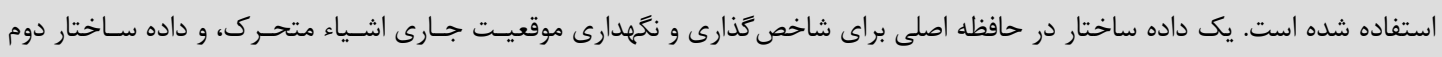

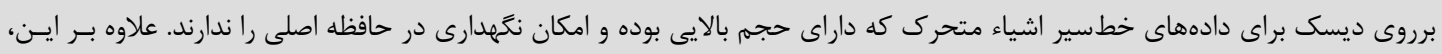

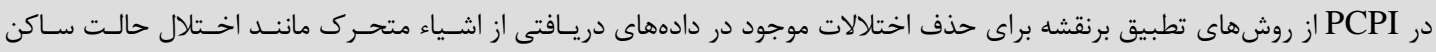

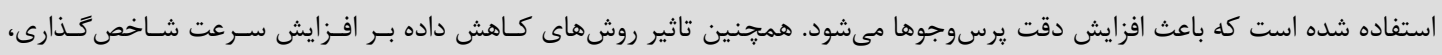

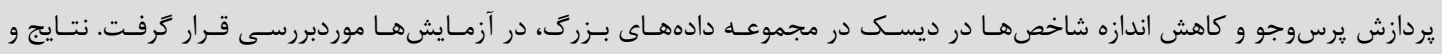

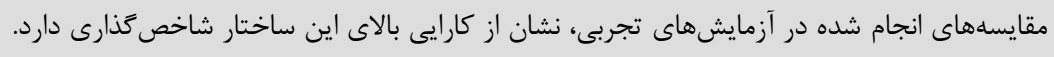

كليدوازهها: ماشين بردار يشتيبان، روشهاى دستهجمعى، فضاى ويزگى، خود راهانداز تصادفى، تلفيق

*نويسنده مكاتبه كننده: تهران، كاركر شمالى، يرديس فنى دانشكاه تهران، دانشكده مهندسى نقشهبردارى و فناورى اطلاعات مكانى. 
رشد حجم دادههاى ذخيره شده بـهـ شـدت بـالا اسـت،

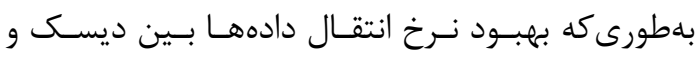

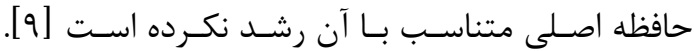

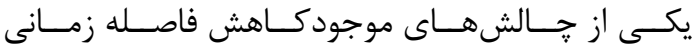
آمادهسازى و بروزرسانى داده در حافظه اصلى و ديسـك موجى

ساختارهاى شاخص گذارى موجود، براى شاخص گـذارى

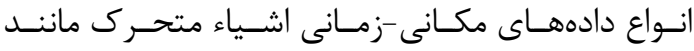
دادههاى خطسير اشياء متحرك (كه مربـوط بــهـ زمــان كذشـته اسـت)، موقعيـت جـارى و يـا موقعيـت آينــده

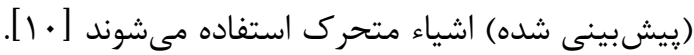

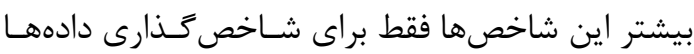
در يكى از سه زمان كذشته، حال يا آينده مورد استفاده قرار مى گيرند. ساختارهايى كه براى شـاخص مَذـارى دو

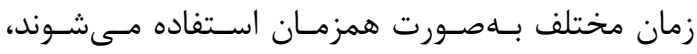

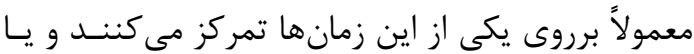
تاكيد برروى يرسوجوى خاصى دارند. نكته ديخرى كـهـ

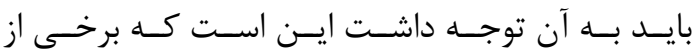

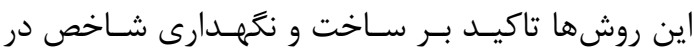

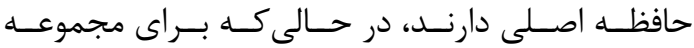

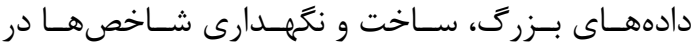

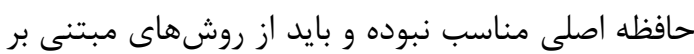

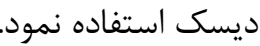

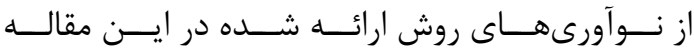

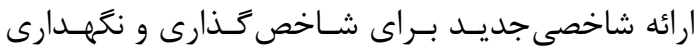

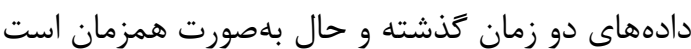

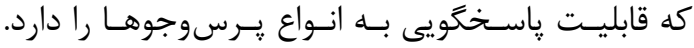

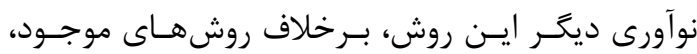

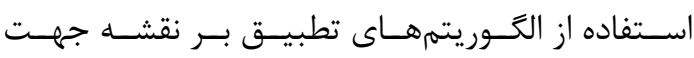
كاهش خطـاى موجـود در دادههـاى ورودى اسـت كـهـ باعث افزايش دقت يردازشها و در نهايـت يـرسوجوهــا

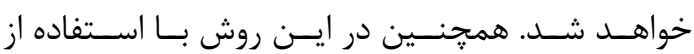
روشهاى كاهش داده امكان شاخص گذارى و نكخهـدارى مجموعه دادههاى بزر خترى را فراهم مى آورد.
|- مقدمه

در سـال هـاى اخيـر ريايخـاهدادههــاى مكـانى -زمـانى بــا تعـداد زيــادى از اشـياء متتحــرك مواجــه هسـتـند كـهـ

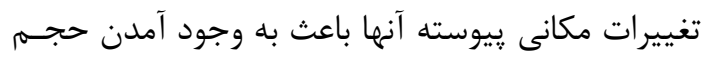

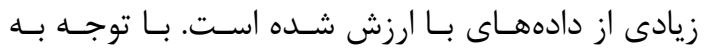
ييشـرفتهــاى زيـادى كـهـ درابزارهــاى آكَاه از محــل، تكنولوزىهاى موقعيتيابى و همجنين ارتباطات بيسيمه،

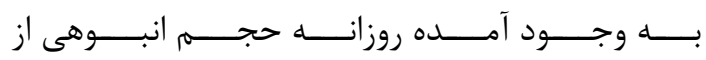

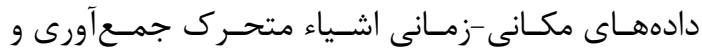
ذخيره مىشود. به دنبال رشد شديد ايـن نـوع دادهـــا، شاهد پيشرفت در سيستمههاى هوشـمند حمـل و نقــل (ITS)

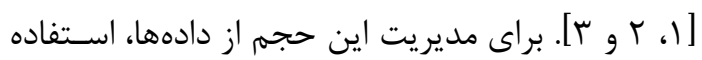

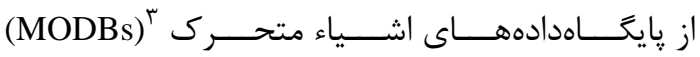

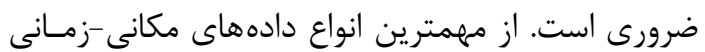

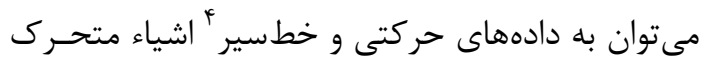

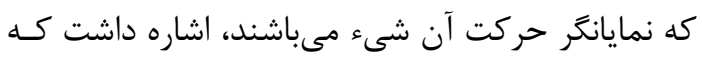
بـهـصـورت يـكـ تـوالى از نقـاط ســه بعـدى (x, y, t) ذخيره مىشوند: دو بعد مختصات جغرافيايى و يك بعـد

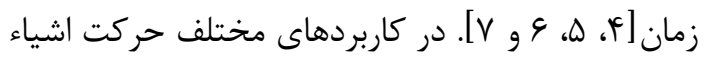

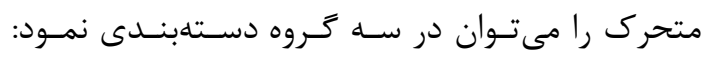
I. حركت بدون محدوديت، r. حركت محسدود شـده و

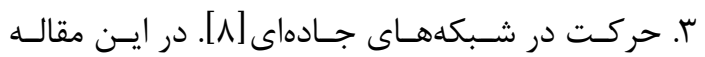
حركت اشياء مانند حركت تاكسىها، اتوبوسها، قطارهـا و حتى افراد محدود به شبكههاى جادهاى است. شاخص گذارى فراهم آوردن اين امكان است كه كاربران بهصورت همروند و كارآمد بتوانند دادههـاى مـورد نيـاز

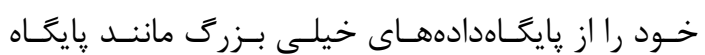
دادههاى مكانى -زمـانى، بازيـابى نمــوده و زمـان ارسـال

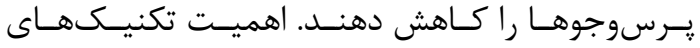

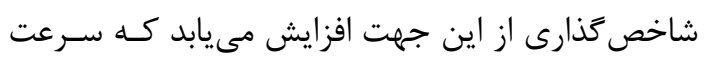

\footnotetext{
${ }^{1}$ Intelligent Transportation Systems

${ }^{2}$ Location Based Services

${ }^{3}$ Moving Object DataBases

${ }^{4}$ Trajectory
} 


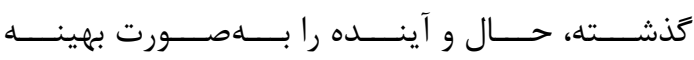

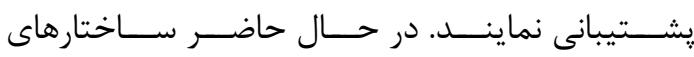
شاخص كذارى متعددى ارائه شده است، در دستهبندى درى

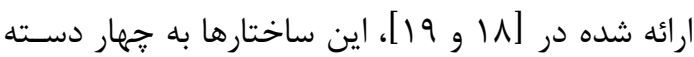

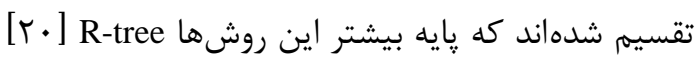

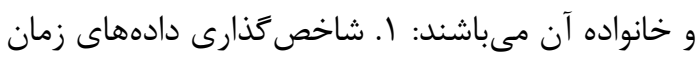

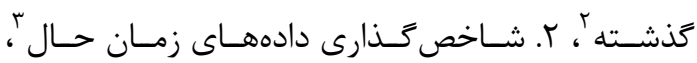

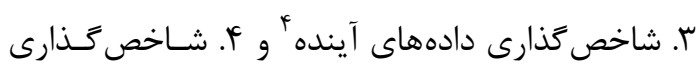
دادههاى در همه زمانها (روش عمومى.)

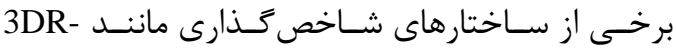

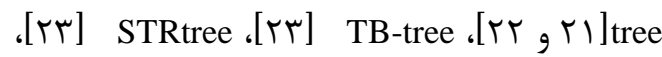
ى [rf, V]SETI, $[r)] M V 3 R-t r e e$ شاخص كذارى و نكمهدارى دادههاى زمان كذشته اشـياء

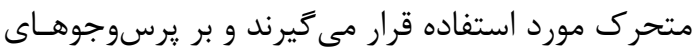

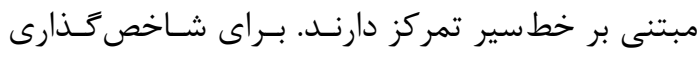

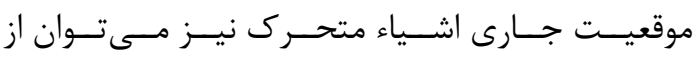

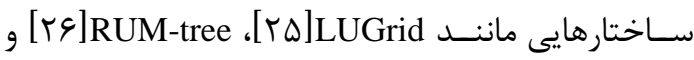
[IMORS

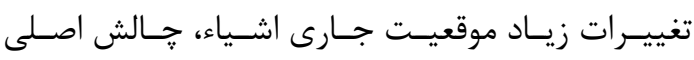

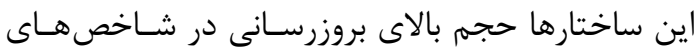

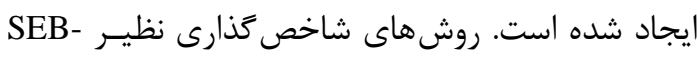

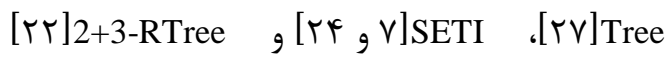

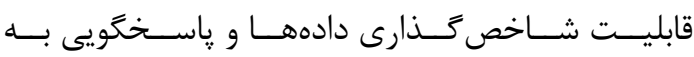
يرسوجوهاى مربوط به زمان حال و كذشته را دارنسد و

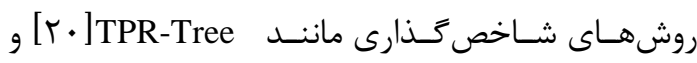

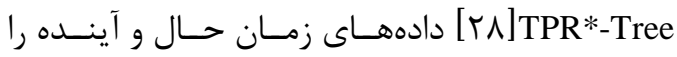

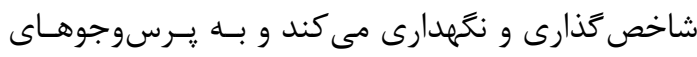

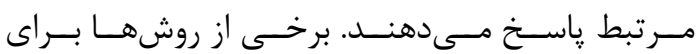

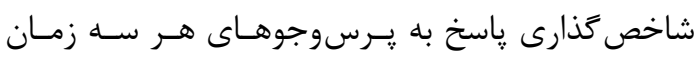

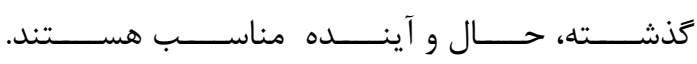

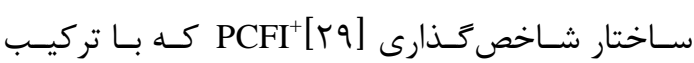

\footnotetext{
${ }^{2}$ Indexing the past data

${ }^{3}$ Indexing the current data

${ }^{4}$ Indexing the future data
}

در ايـن مقالـه سـاختار شـاخص عَـذارى بــا نـام PCPI'

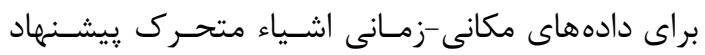
شده است. در اين روش، دادههاى موقعيت جارى اشـياء متحرك در حافظه اصلى و بـا اصـلاح و بهبــود سـاختار

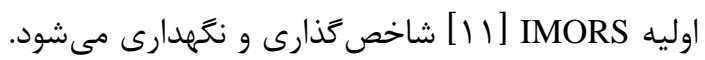
همجنين شاخصهاى دادههاى خطسير برروى ديسـى ايجاد و نتحهدارى مى شـود. در PCPI، از يـك مجموعـهـ

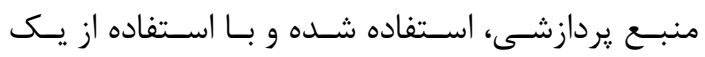

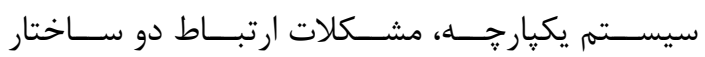
شاخص گَذارى را كـاهش داده اسـت. همجنــين حجـهم بالاى دادهها و اخـتلالات زيـاد موجـود در ايـن دادههــا

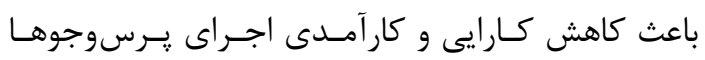

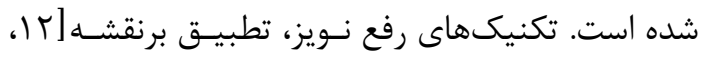

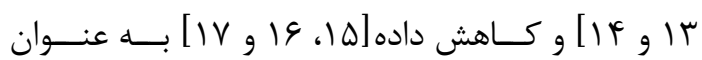
״يش يردازش شاخص گذارى در اين مقاله يِيشنهاد شده

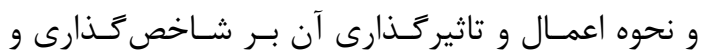
يردازش يرسوجو بررسى شده است. با اسـتفاده از ايـن

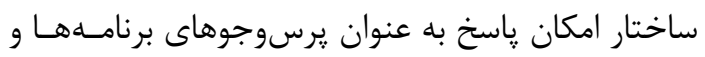

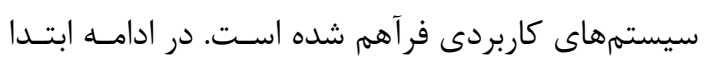

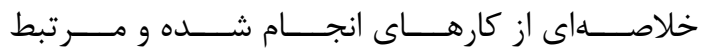
بررسـى مـى شــوند. سـيس در بخــش سـوم سـاختار شاخص گَذارى PCPI مطــرح و همجنــين نحسوه انجـام ييشيردازش بررسى مى گردد. در بخـش جهــارم نتـايج

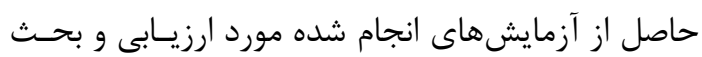

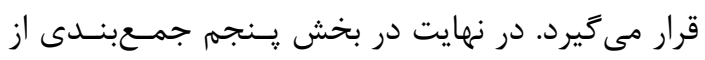

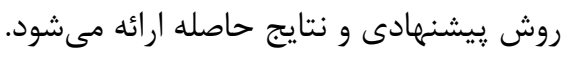

\section{r - كارهاى مر تبط}

در پاييًاه دادههاى اشياء متحرك، ايدهآل اين اسـت كـهـ ساختارهاى شاخص كذارى كارآمدى استفاده شـود كـهـ

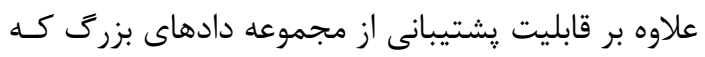

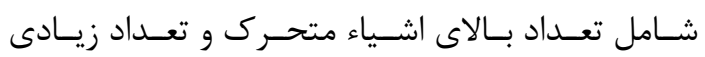
خطسير است، موقعيت اشياء متحرك در هر سه زمـان

${ }^{1}$ Past and Current Position Indexing 
بالا، برروى ديسك شاخص كذارى و نتخهدارى مسىشـود.

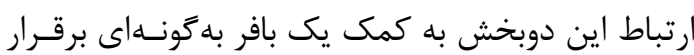
مىشود كه وقتى موقعيت اشياء متحرك تغيير مى كنـد،

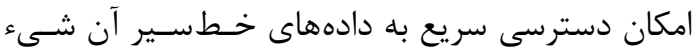

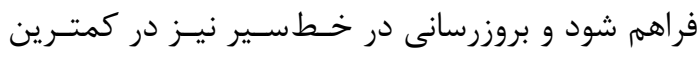

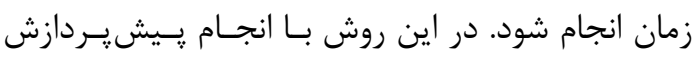
برروى دادهها، كيفيت دادهها افزايش يافته و در نتيجـهـ

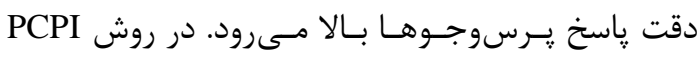
دادهاى خام اشياء متحرك، بـه دو روش وارد سيسـتم مىشوند. بخشى از اين دادهها كه موقعيت جارى اشسياء

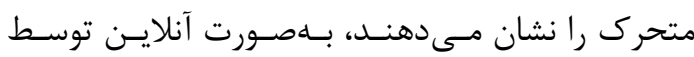

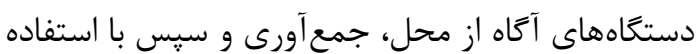

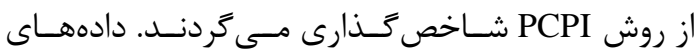
خطسير اشياء متحرك كه قبلاً توسط ايـن دسـتخاهــا،

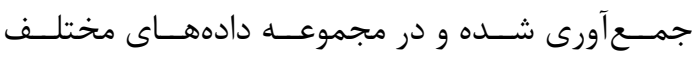

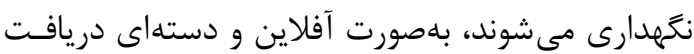

$$
\text { و سيس شاخص كذارى مى كردند. }
$$

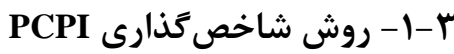

همانكَونـهـ كـه در شـكل ( ) مشـاهده مسىشـود، روش در دو بخش شـاخص حـذارى را انجـام مسى دهــد.

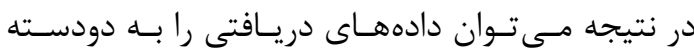

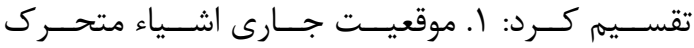

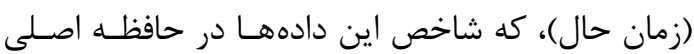
M-Index ايجاد و نكمهدارى مى شود و در شكل با با عنوان ادهان

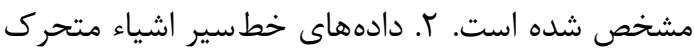

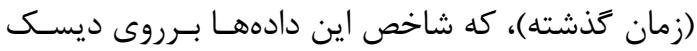

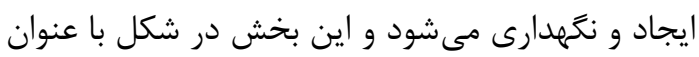

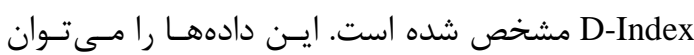

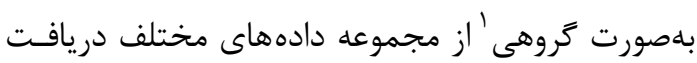

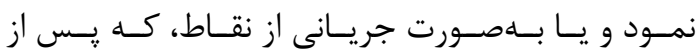

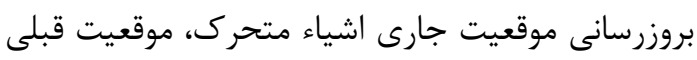

${ }^{1}$ batch

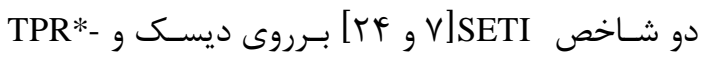

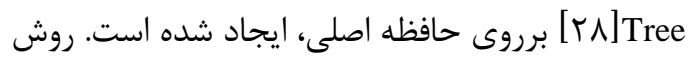

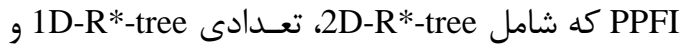
يـك داده سـاختار درهـمســازى مسىباشـد، عـلاوه بـر

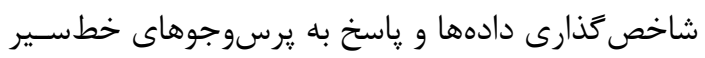

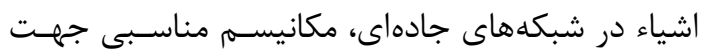
بروزرسانى هاى موقعيت جارى اشياء متحرك و ياسخ به

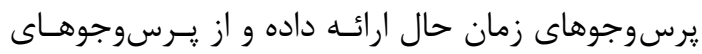

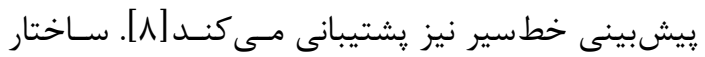

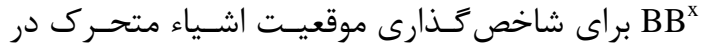

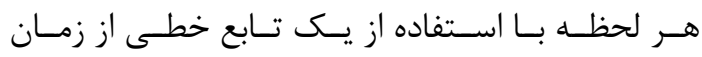

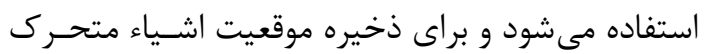

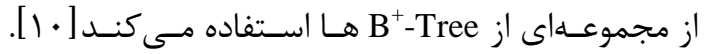

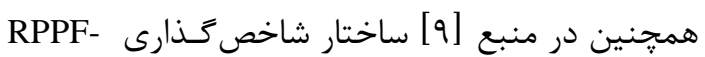

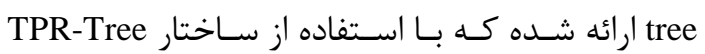

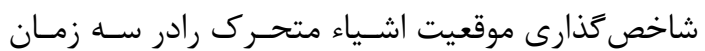
حذشته و حال و آينده انجام مى دهد.

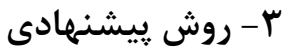

حجم بالاى دادهاى مكانى-زمانى و همجنين تغييـرات

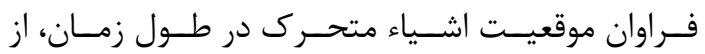

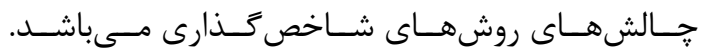
اين تغييرات نياز به حجم بالايى از بروزرسانىهـا دارنـد.

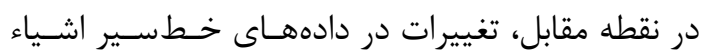

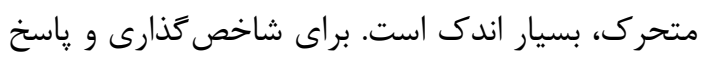

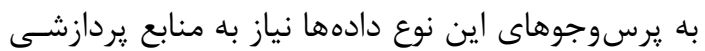

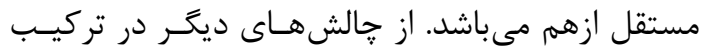

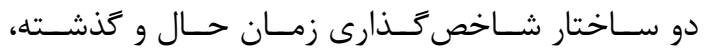

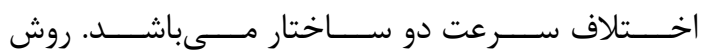

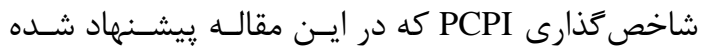

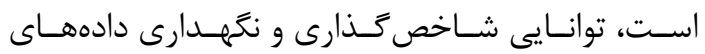

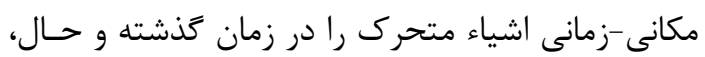

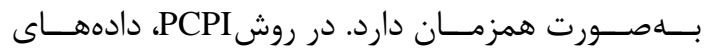

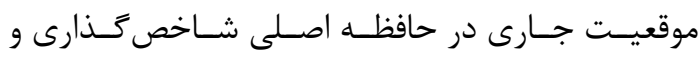

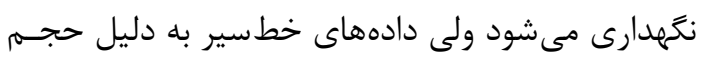




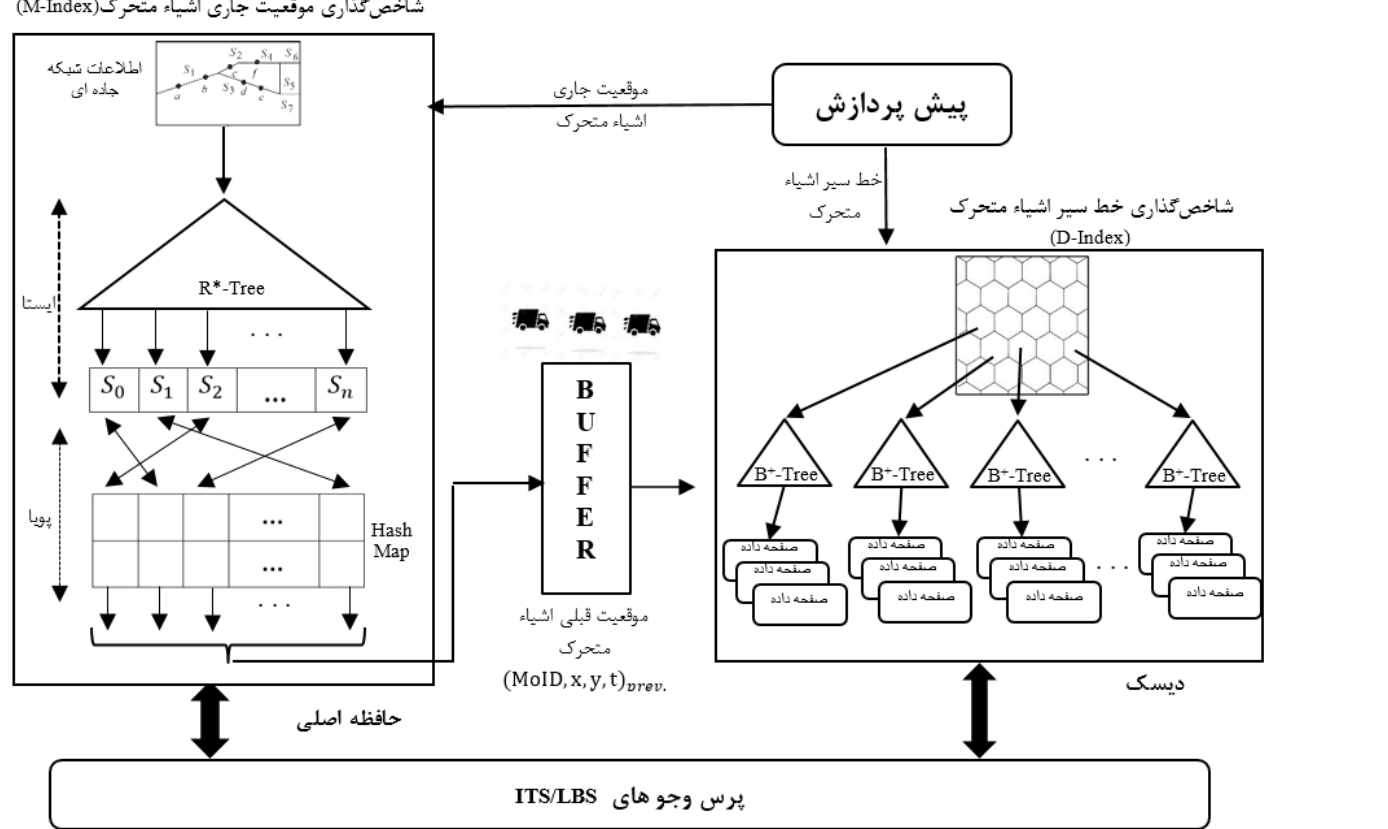

شكل ا: ساختار شاخص كذارى PCPI

منطبق بر شبكه تبديل مى شوند. همانطور كه در بخش M-Index

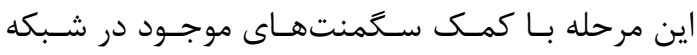

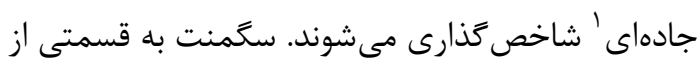

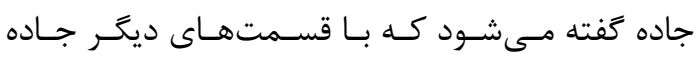

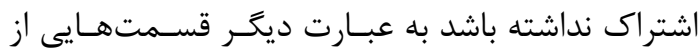
جاده كه مىتوان آنها را بهصورت يك افراز تقسيم كرد.

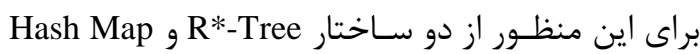

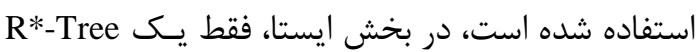
براى سخمنتهـاى شـبكه جـادهاى سـاخته مسى شـود.

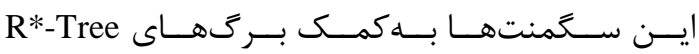
قابــل دسترسـى هســتند. در ايسـن بخـــ R*-Tree مشابه ديكر R*-Tree ها استفاده مىشود، با اين تفـاوت

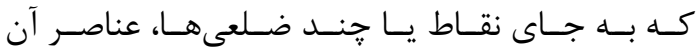

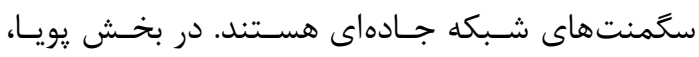

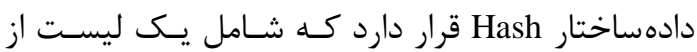

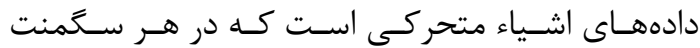

${ }^{1}$ Road Network
ץ-1-1 - شاخص كــذارى موقعيـت جــارى اشـياء متحرى يكى از ويزَّى هاى اصلى شاخص گذارى موقعيت جـارى

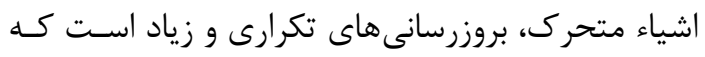

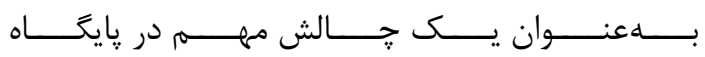

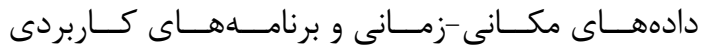

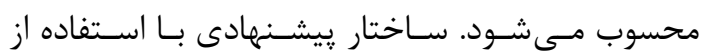

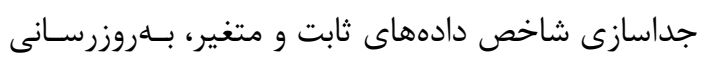

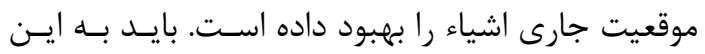

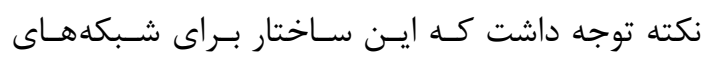

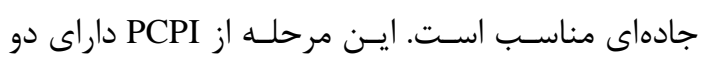

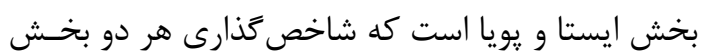
در حافظه اصلى انجام مىشود. بخش ايستا بدون توجـهـ

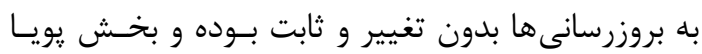

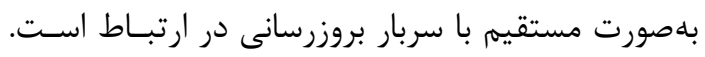

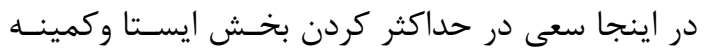

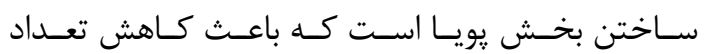

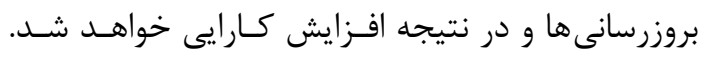

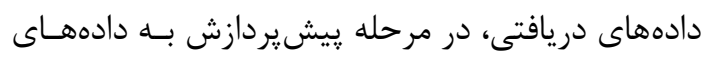


r-1-Y- شاخص כذارى خطسير اشياء متحرى

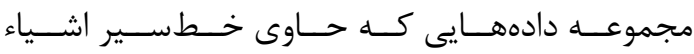
متحرك است، بهصورت كروهى دريافت و پِ از انجـام

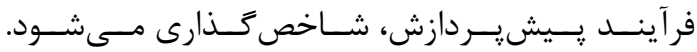

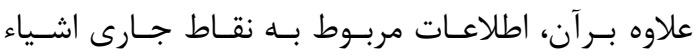

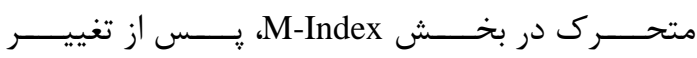
موقعيت شىء و بروزرسانى آن، بايد به ادامـه خـطســير اشياء در بخش D-Index اضافه شود. براى اين منظور و

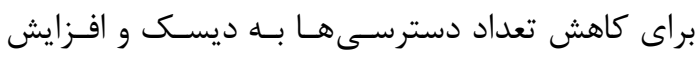
سرعت شاخص كذارى، اطلاعات موقعيت مكـانى -زمـانى

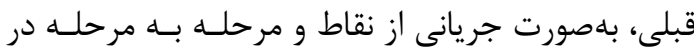

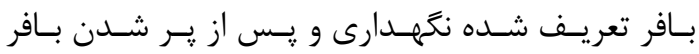

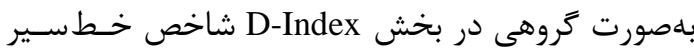
مربوطه را يافته و آن را بروزرسانى مى كند. سـاختارهاى شاخص متعددى براى اطلاعات فضـايى ييشــــهاد شـده

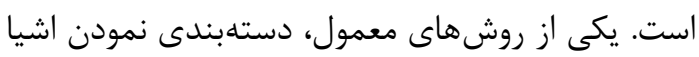

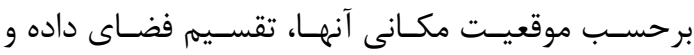
ذخيرهسازى دستههاى ايجادشده بهعنـوان صـفحات در

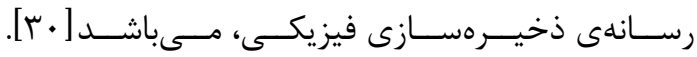

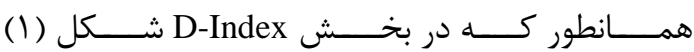
مشخص شده است، در روش PCPI براى شاخص كذارى

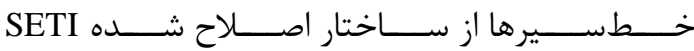

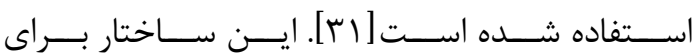

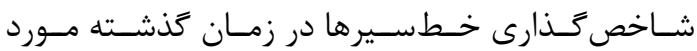
استفاده قرار مى گيرد. به دليل وجود تفاوت هاى اساسى

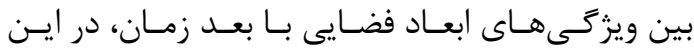
ساختار، شاخص كذارى ابعاد فضايى و زمانى از هم جدا

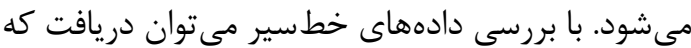

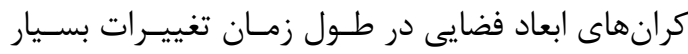
كمى دارند. در حالى كه بعد زمان به طور دائم در حسال افزايش است. به دليل اينكه ابعاد فضايى داراى تغييرات كمى هستند، اين روش بلهورت منطقى محدوده فضـا را به سلول هاى ششضلعى استاتيك و بدون هميوشانى

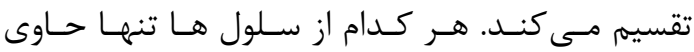

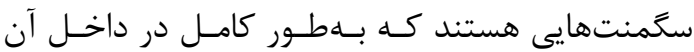

قرار دارند. كليد Hash استفاده شده، ID متناسب بـا آن

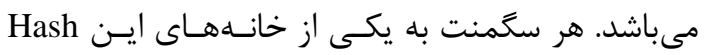

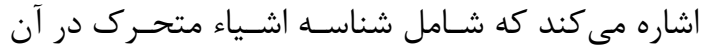

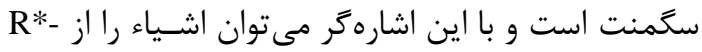
بازيابى نمود. علاوه برآن دادههاى ديخرى مـرتبط

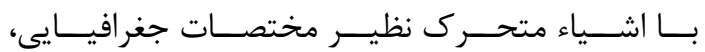
شناسه خطسير، سرعت و ديخر ويزگى هــاى مـرتبط بـا

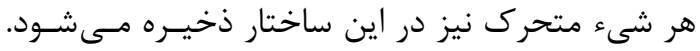

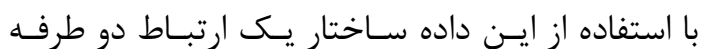

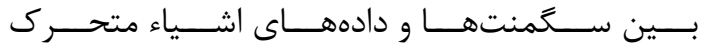

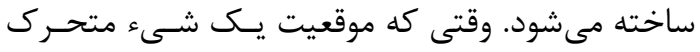

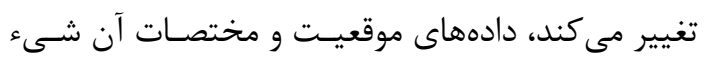
در ساختار Hash بروزرسانى مىشود و اكر سخمنت نيـز

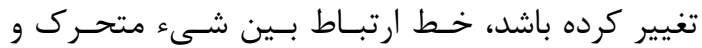

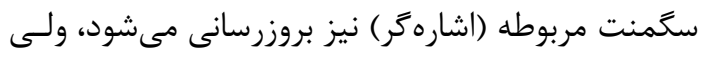

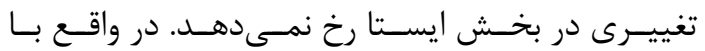

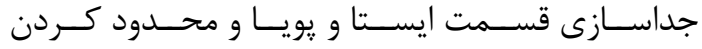
بروزرسانى ها، تنها به قسمت بويا، باعث افزايش سـرعت

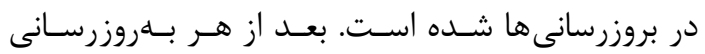

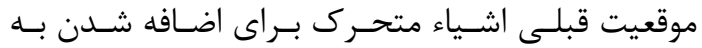

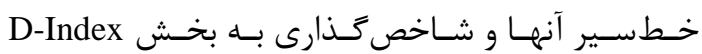

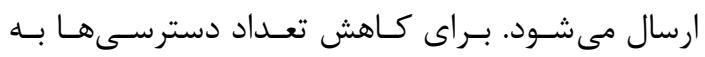
ديسك، اطلاعات اشيائى كه موقعيت آنها تغيير كـرده و بروزرسانى شده است و بايد به شاخص خطسـير شـى شيء

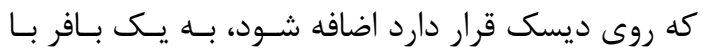
اندازه برابر با نصف اندازه بافر ديسك، منتقل مسى ديسود. ايـن اطلاعــات شـامل $)$

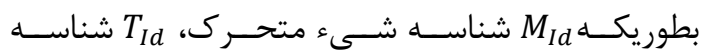

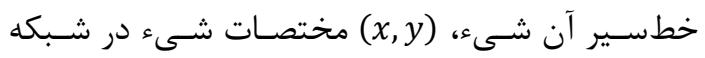

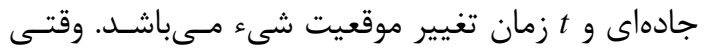

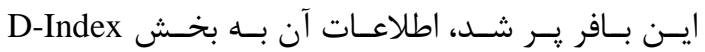

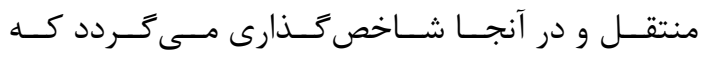

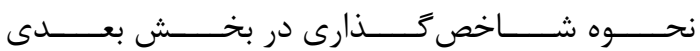
شرح داده شده است. 


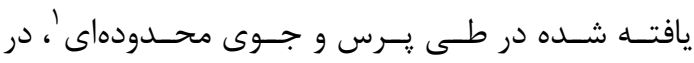

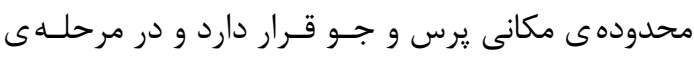

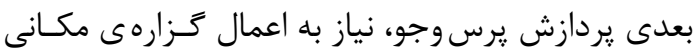

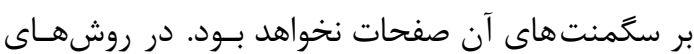

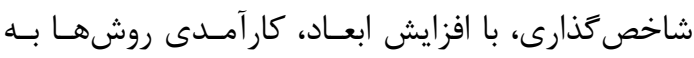
شدت كاهش مى يابد. از آنجايى كه در PCPI از شاخص يك بعدى استفاده شده است، ساختار شاخص گذذارى بـا

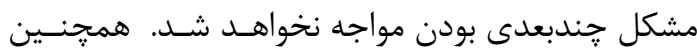

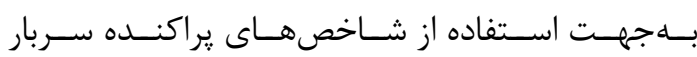

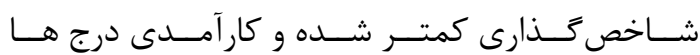

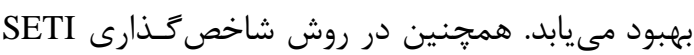

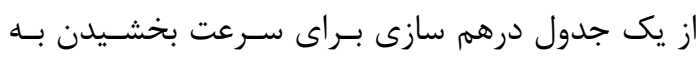

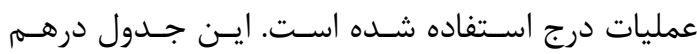

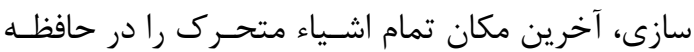

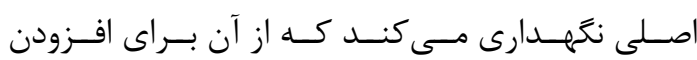

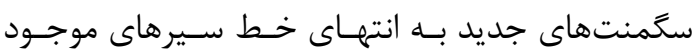

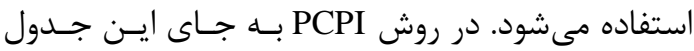

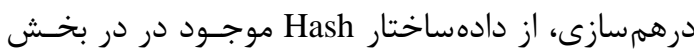
M-Index

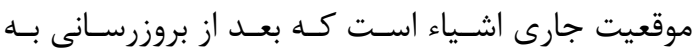
خطسير هر شىء بـرروى ديسـى اضـافه مسىشـود. بــاء

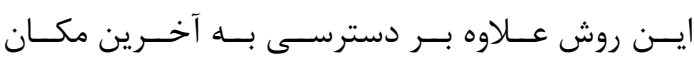

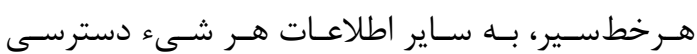

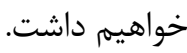

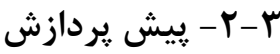

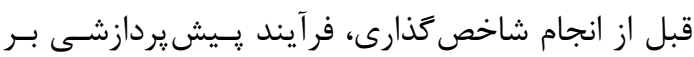

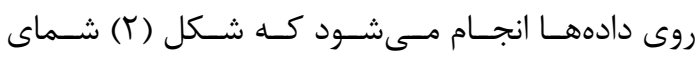
سطح بالا از فر آيند را نمايش مى دهد. در اين فرآينــد از

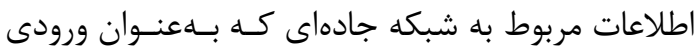

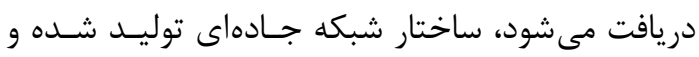
سيس با در دست داشتن ايسـن سـاختار، دادهــاى خـام

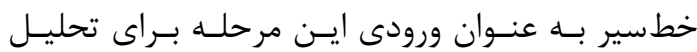

سلول قرار مى كيرند. اخر سگمنتى از خطسير بلهورت

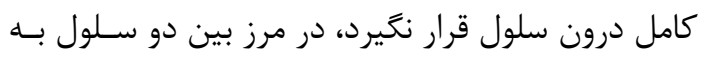

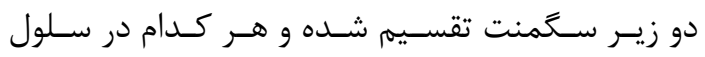

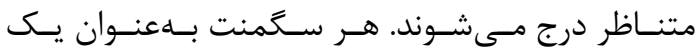

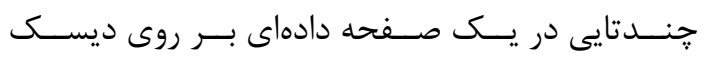

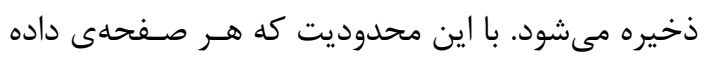

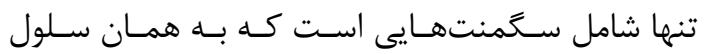

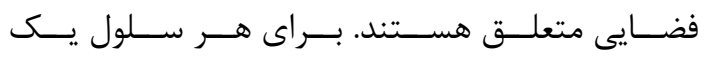

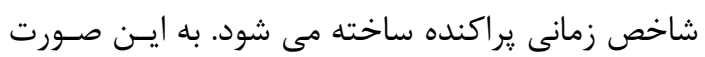

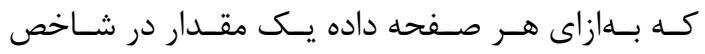

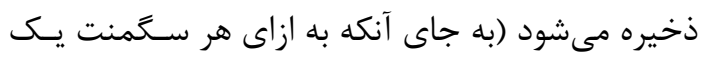

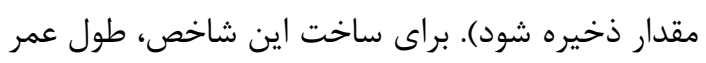

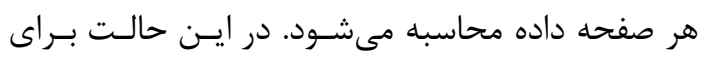

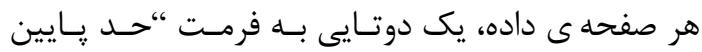

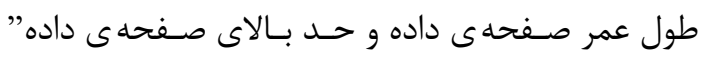

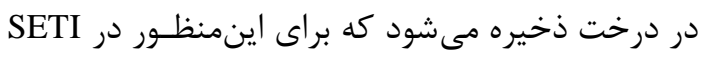
از درخت R* براى استفاده مى شـود. بنـابراين در اينجـا

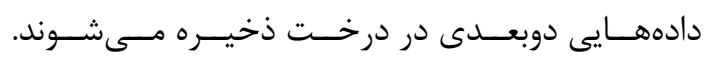

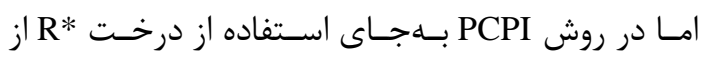

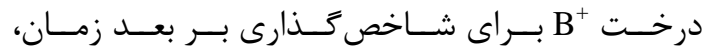

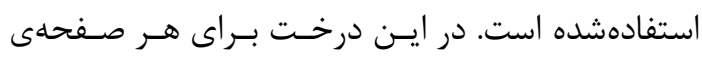

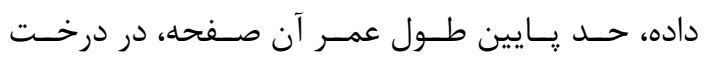

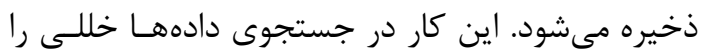

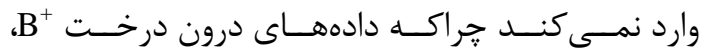

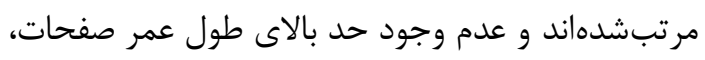

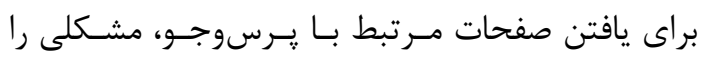

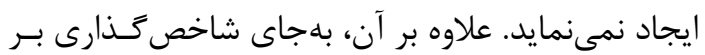

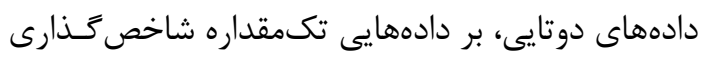

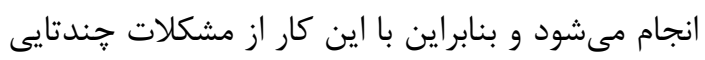

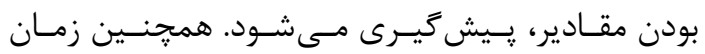

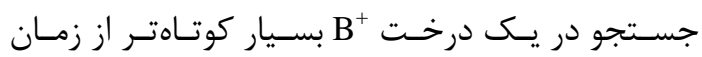

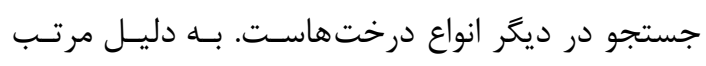
بودن مقادير در درخت Bم، طـول عمـر اكثـر صـفحات

\footnotetext{
${ }^{1}$ Range query
} 


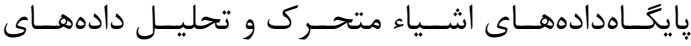

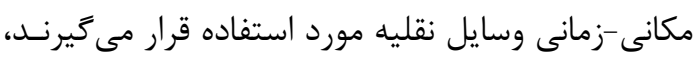

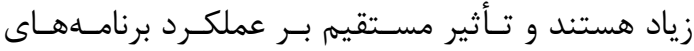

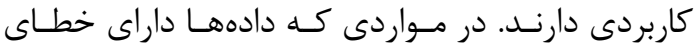

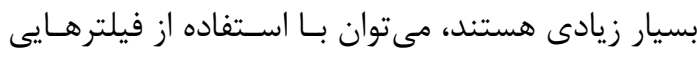

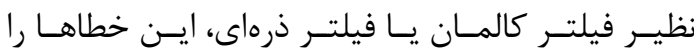
از بين برد. اما در بسيارى از موارد كه خطـاى مـوردنظر

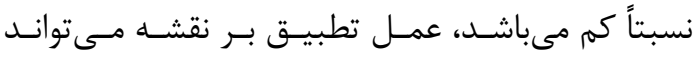
راهخشا باشد.
دادهـــاى مكـانى -زمــانى در محــيط شـــكه جــادهاى،

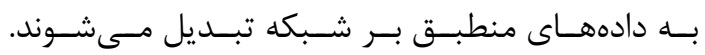
اين دادهها، به دليـل اخـتلال حســر در دسـتـاهــاى مكـانيـابى، سـيكَنال ضـعيف مـاهوارهاى در فضـاهاى متراكم شهرى و عوامل مختلف ديخـر، هـيجتحـاه كـاملاً

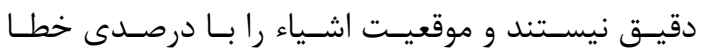
كزارش مى كنند كه در برخى موارد ايـن خطاهـا بسـيار

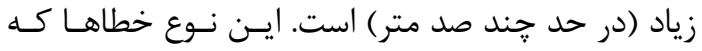

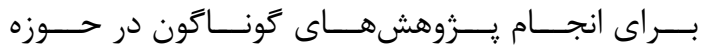

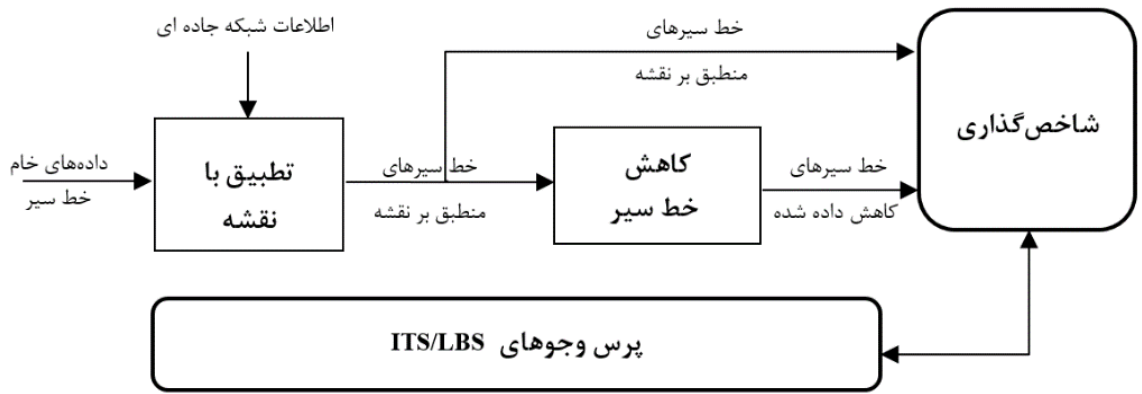

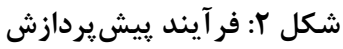

ذدف روشها كـاهش داده، كـاهش ســبار ارتباطـاتى و

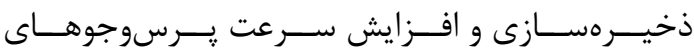

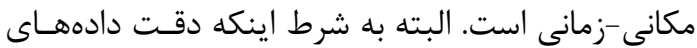

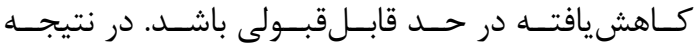

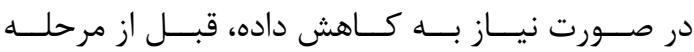
شاخص كذارى، با بهره خيرى از خوشهبندى خـطسيرها

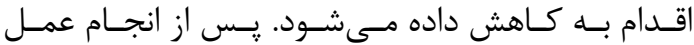

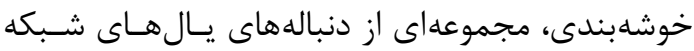

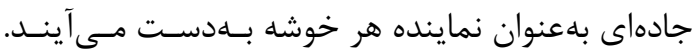
با استفاده از اطلاعات استخراجشده از ايـن نماينـدهـــا، عمل كاهش داده بر روى خطسيرهاى منطبق بر نقشـهـ

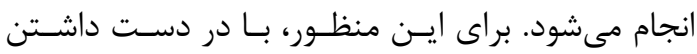
خوشههاى كشفشده، ابتدا نياز است كه بخشهـايى از

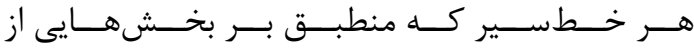

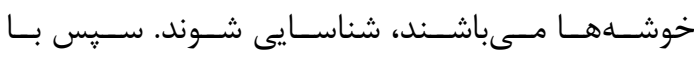
خواندن نقـاط هـر خـطسـير، يـك دنبالـه از يـالهــاى ييموده شده در طى خطسـير جـارى ايجـاد مسى شــود.

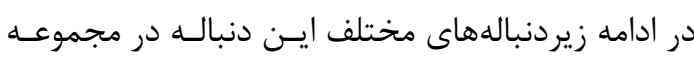

انجام عمل تطبيق بر نقشــه در مـواردى مانـــــ اخـتلال حالت ساكن'، يُلهاى روكَّر و راههـاى مـوازى، مســاله

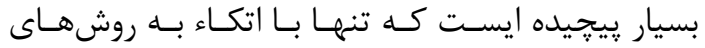
معمول هندسى نظير تطبيق نقطه بر نزديكترين خيابان

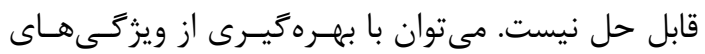

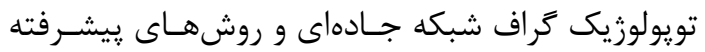

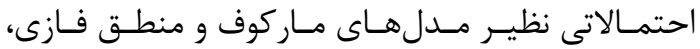
به دقت قابل قبولى در اين زمينه دست يافت. روشهاى نداى

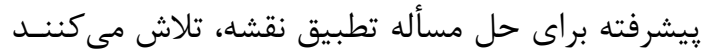
تا دنبالهاى از يالهاى شبكه را بيابند كه هم به منحنسى ساخته شده از حركت شىء متحـرك نزديــ باشــند و هم يك مسير منطقى در شبكه جادهاى را شامل شـوند. اين روشها همواره تلاش مى كنند تا توازنى بين تطبيق

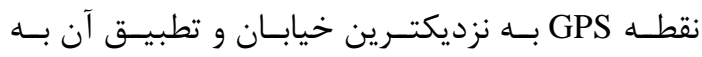

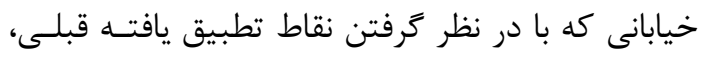
بامعنىتر است، برقرار سازند.

${ }^{1}$ stationary state noise 
I I \&V.

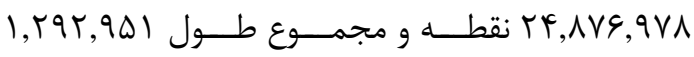

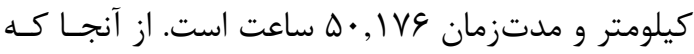

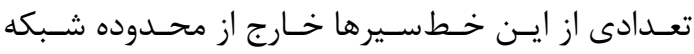

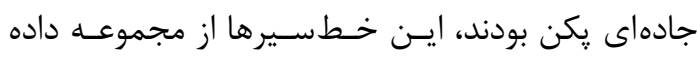

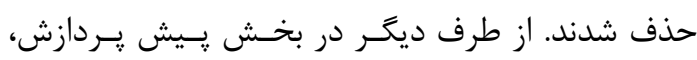

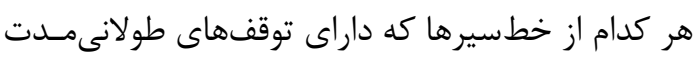

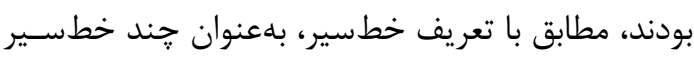

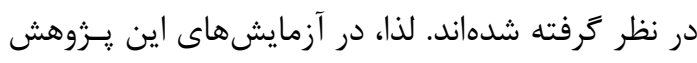

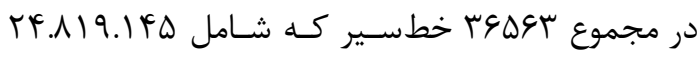

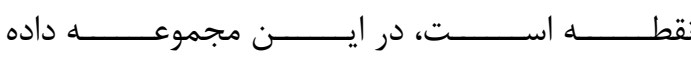

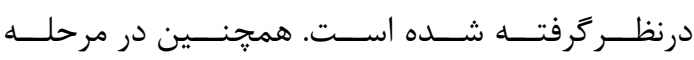

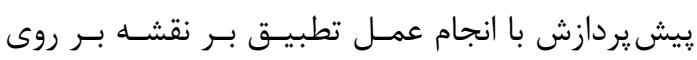

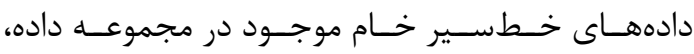

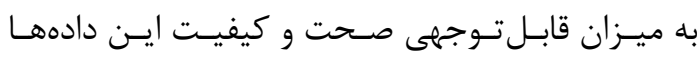

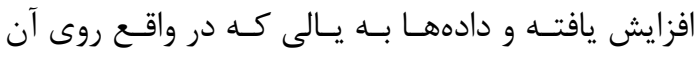

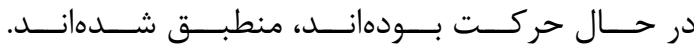

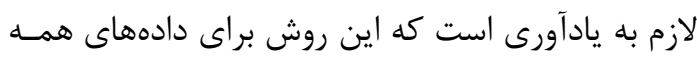

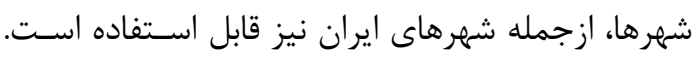

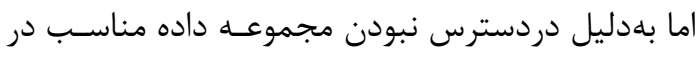

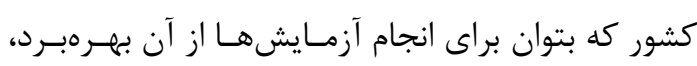
اين آزمايش برروى مجموعه داده Geolife انجام شد.

\section{F-1- ارزيابى نتايج بخش كاهش داده}

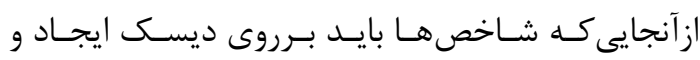

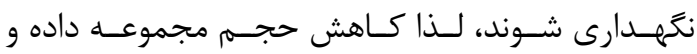

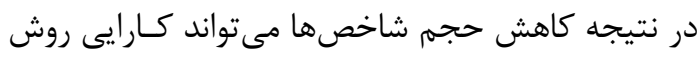

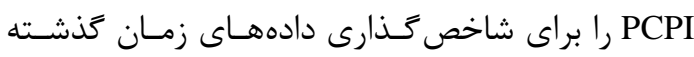

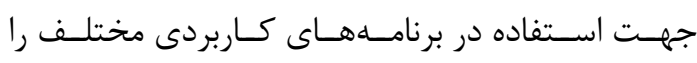

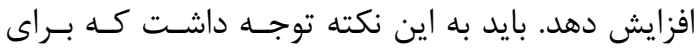

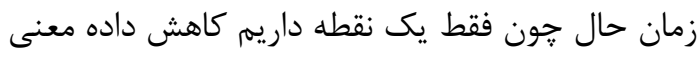

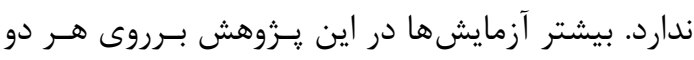
مجموعه داده اصلى و كاهش داده شده انجام شده است

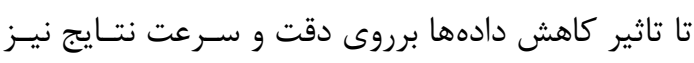

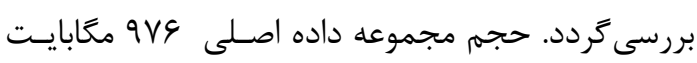

خوشهها را با اسـتفاده از داده سـاختار تـراى ســ كَانـهـ

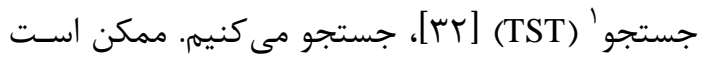

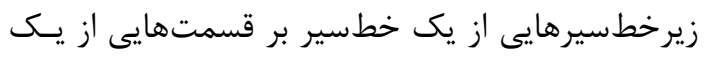

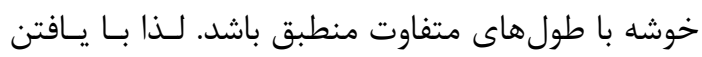

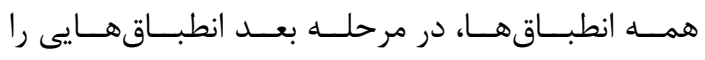

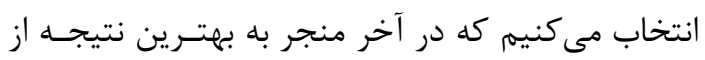

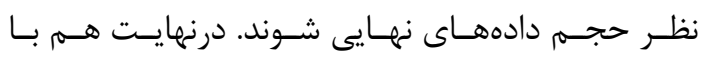

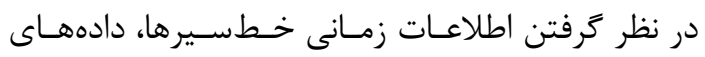

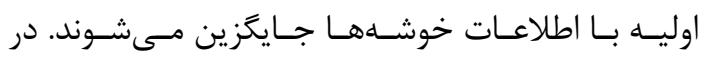
اين مرحله با بهره خيرى از درونيـابى، اطلاعـات زمهانى

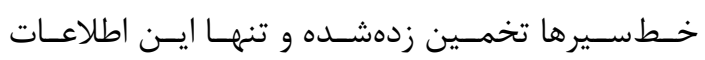

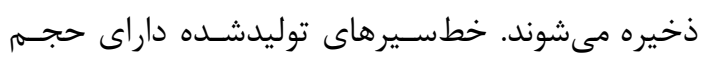

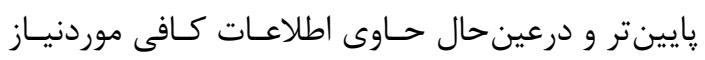

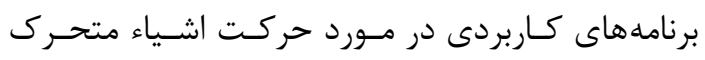

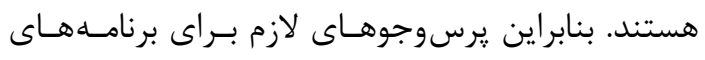

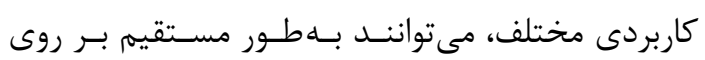

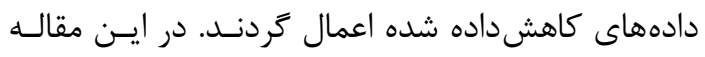

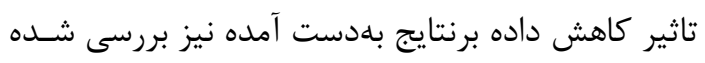
است كه در ادامه شرح داده شده است.

\section{F - ارزيابى روش بيشنهادى}

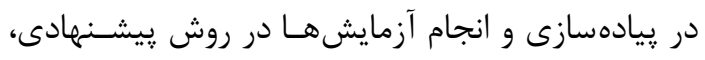

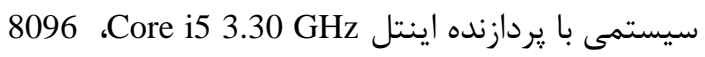

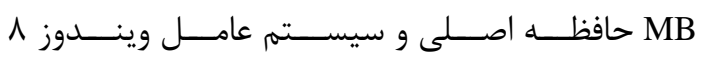

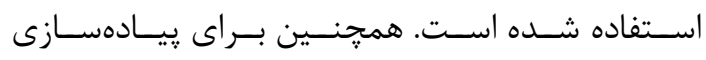

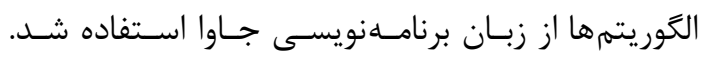

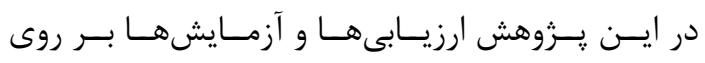

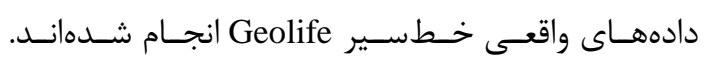

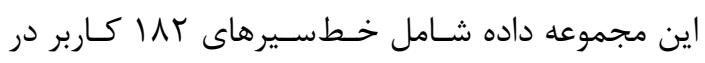

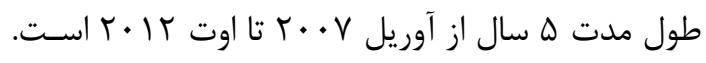

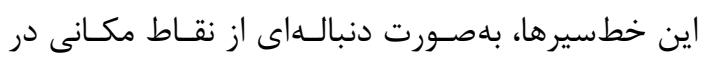

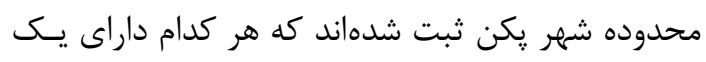
مهر زمانى مى باشند. تعداد خطسـيرهاى ايـن مجموعـهـ

${ }^{1}$ Ternary Search Trie 
همجرنين براى بررسى تأثير روش PCPI بـر روى زمـان

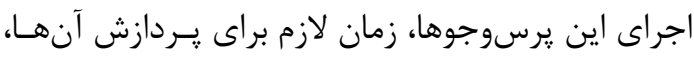

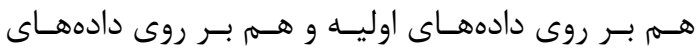

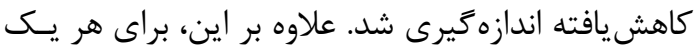

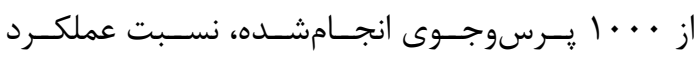

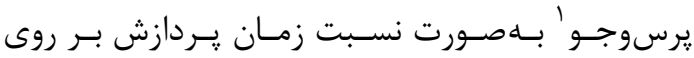

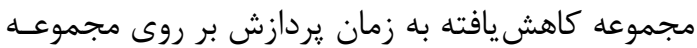

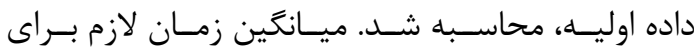
يـرسوجـوى WhereAt و WhenAt در شكل(r-الـف)

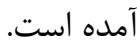
از آنجا كه تعداد نقاط مجموعـهـ داده كـاهش دادهشـده،

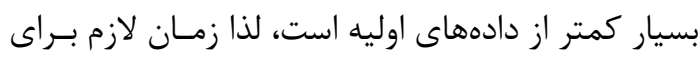
يردازش اين برسوجوها، در دو حالت ذكرشـده، تفـاوت

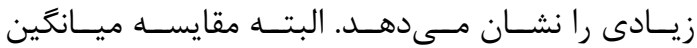
اين زمانها، نمىتواند معيار خوبى براى توصيف ميـزان

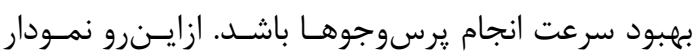
ميانگين نسبت عملكرد برسوجو براى اين برسوجوهـا

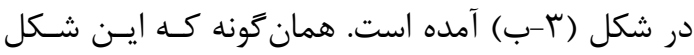

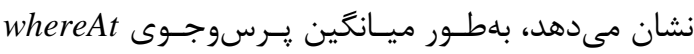

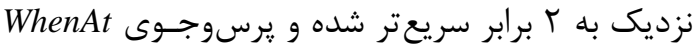

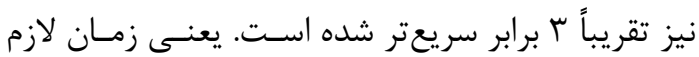

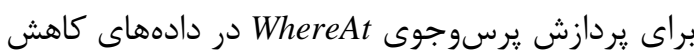

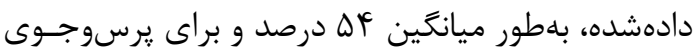

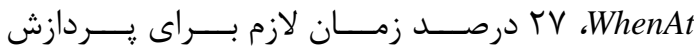

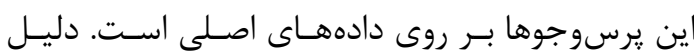
تفاوت در ميزان سريعشدن اين دو يرسوجو، روئ تفاوت در

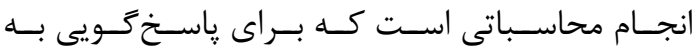
اين يرسوجوها مورد نياز است.

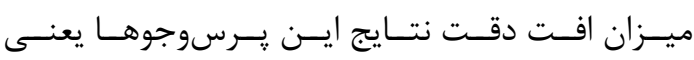
حداكثر خطاى قابلتحمل توسط برنامه كـاربردى بـراى

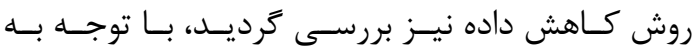

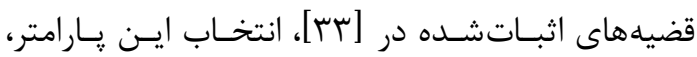

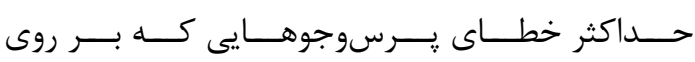

\footnotetext{
${ }^{1}$ Query Performance Ratio
}

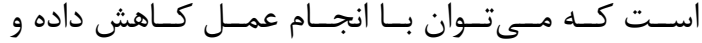

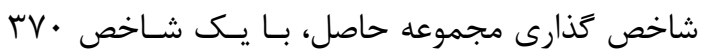
معابايتى اين مجموعه داده را بهصورت بهينه در حافظه

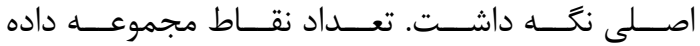

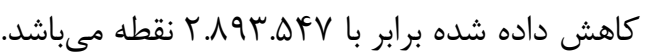

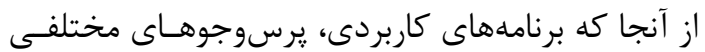

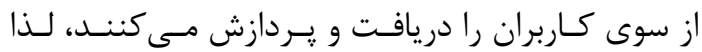

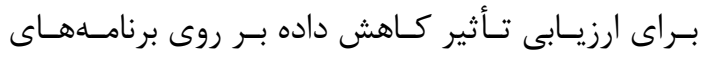

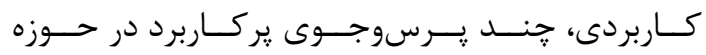

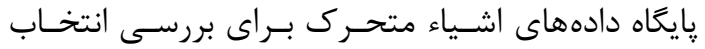

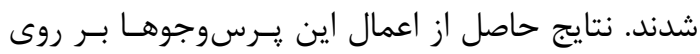
دادههاى كاهش يافته مىبايست مشابه نتـايج حاصـل از ازئ اعمال همان يرسوجوها بر روى دادهاى اصلى باشــند.

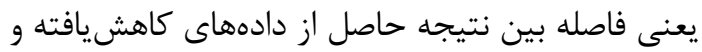

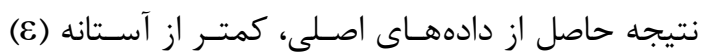

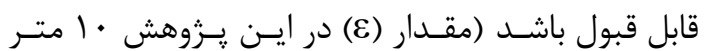
مىباشد). براى اين ارزيابى، سه يرسوجـوى WhereAt،

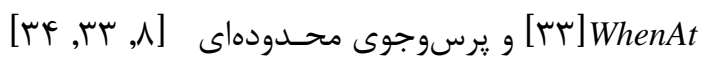

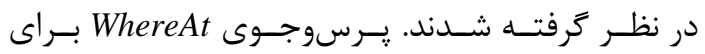

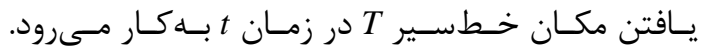
منظور از مكان خطسير T همان مكان شـء متحركى

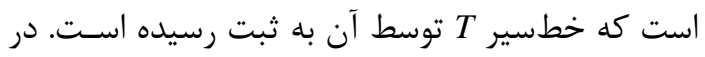

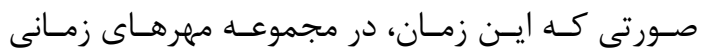

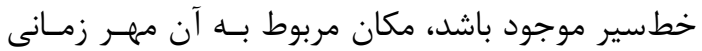

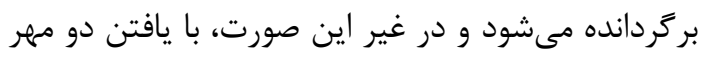

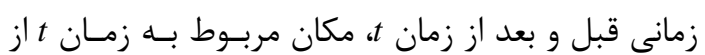

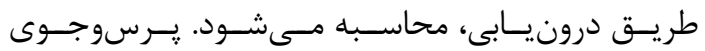
WhenAt

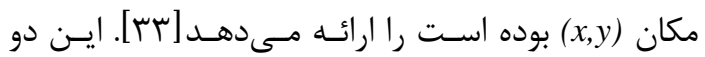

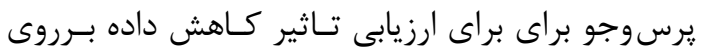

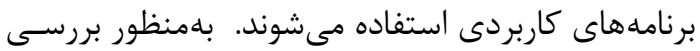

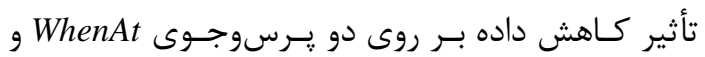
WhereAt زمانى، بلهورت تصادفى در محدوده دادههاى مجموعـهـ

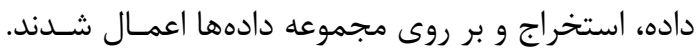




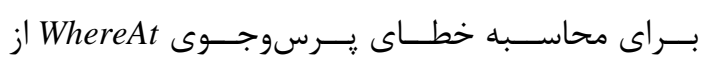
رابطه (1) استفاده شده است.

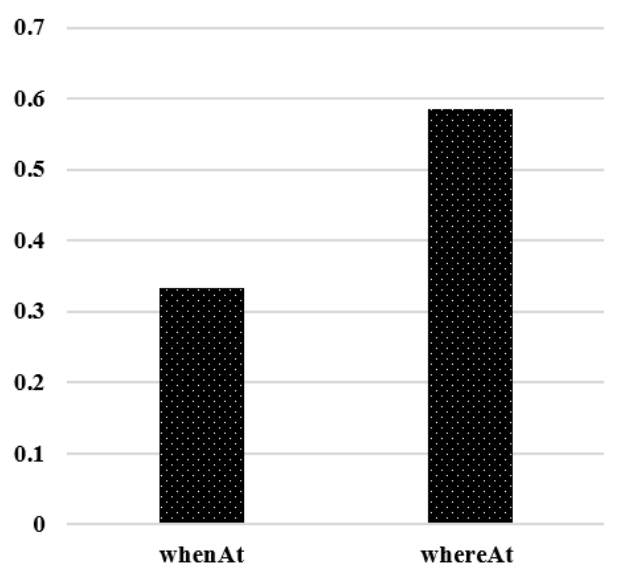

دادههـاى كـاهش دادهشـــ اعمـال مسىشـوند را نيـز

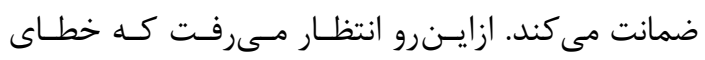

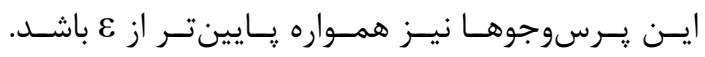

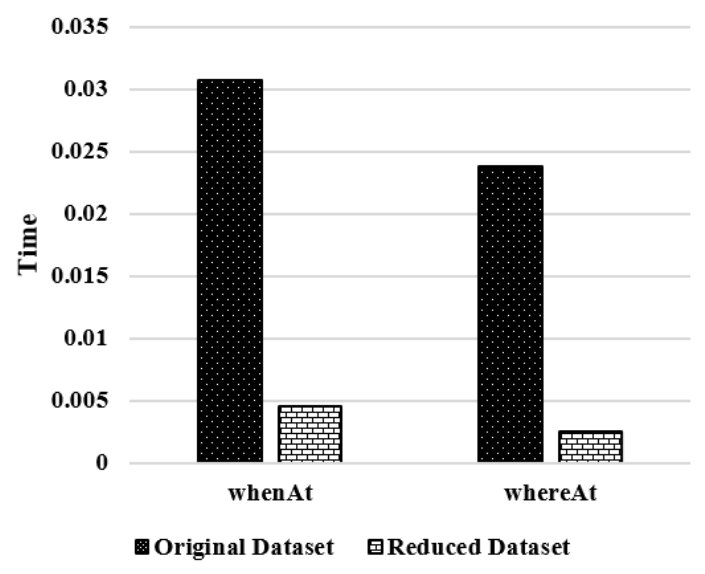
شكل r: الف.ميانكَين زمان لازم براى برسوجو WhereAt و WhenAt - ب. ميانَين نسبت عملكرد يرسو جو

distance $=\operatorname{dist}\left(\operatorname{WhereAt}(T, t)\right.$, WhereAt $\left.\left(T^{\prime}, t\right)\right)=\operatorname{dist}\left((x, y),\left(x^{\prime}, y^{\prime}\right)\right)$ رابطه (1)

وجود اختلال هاى بسيار زياد اين دادهها مانـــد اخـتلال حالت ساكن است كه با توجه به مزايايى كه دارد از اين ميزان مى توان جشم يوشى كرد.

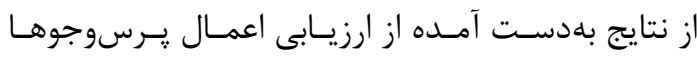

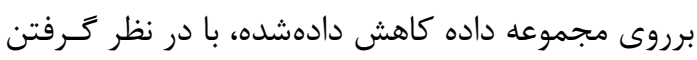

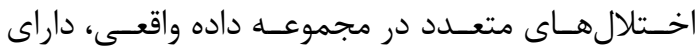

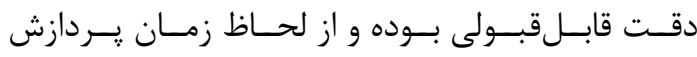

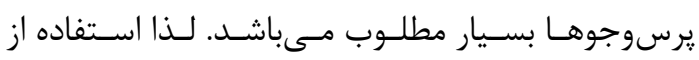

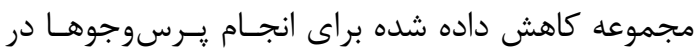

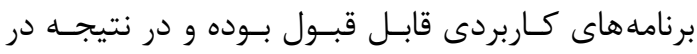

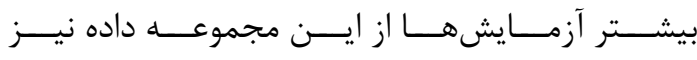
استفاده شده است.

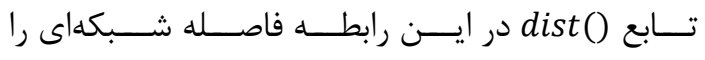

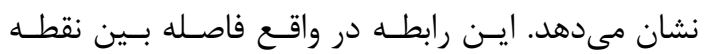

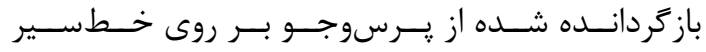

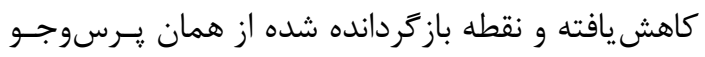

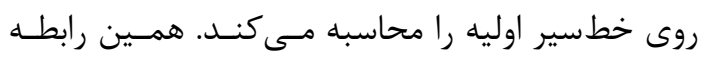

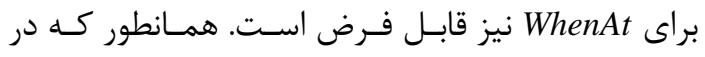

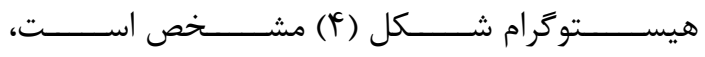

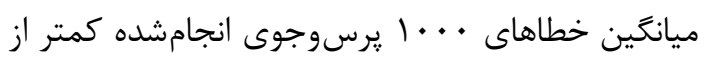

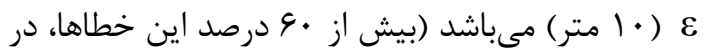

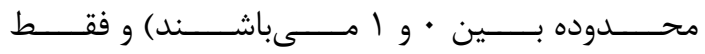

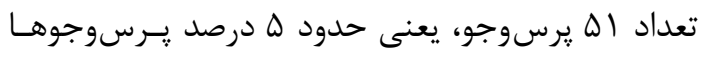

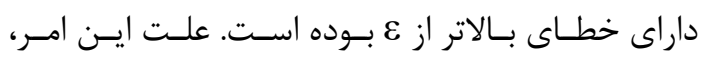




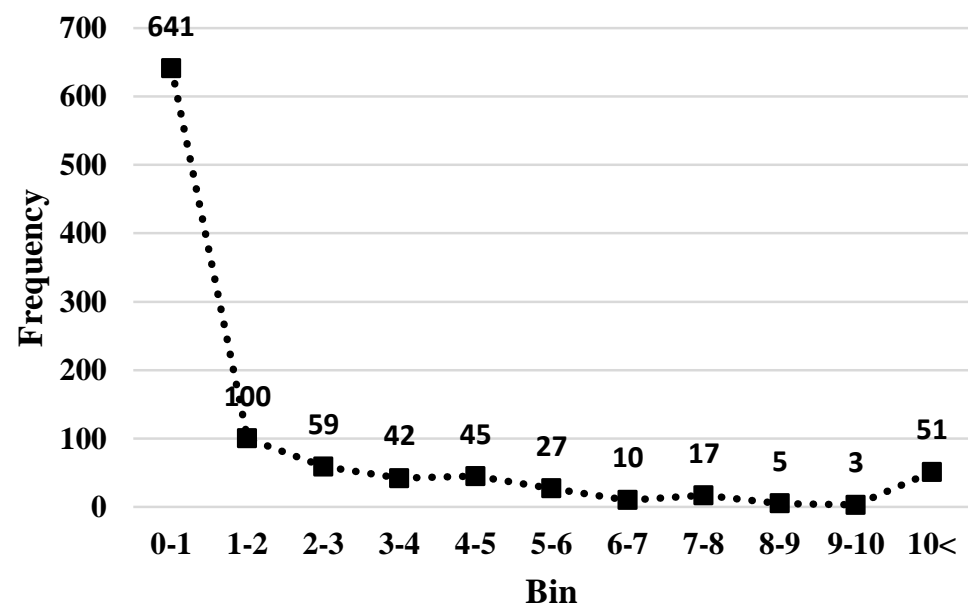

شكل f: ميانگين خطاهاى •..1 يرسوجوى انجام شده

بdمنظور ارزيابى تاثير حجم مجموعه داده برروى سرعت

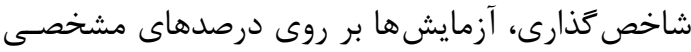

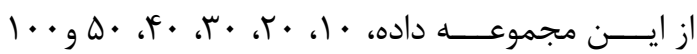
درصد دادهها انجام شد. سيس بر بر روى هــــ مجموعــه از

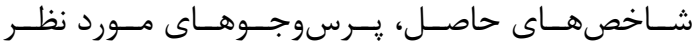

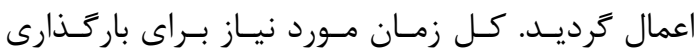

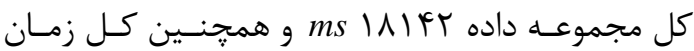
موردنياز براى باركذارى سـحمنتهـاى شـبكه جـادهاى

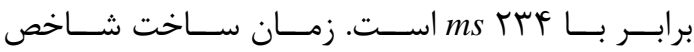

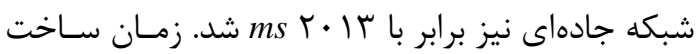
شاخص براى درصدهاى مختلف از مجموعه داده نيز در

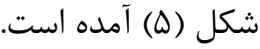
تعداد بروزرسانى هاى انجام شده براى كل مجموعه داده

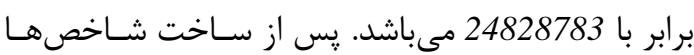
براى ارزيابى بهتر اين بخش در برنامههاى كـاربردى، دو

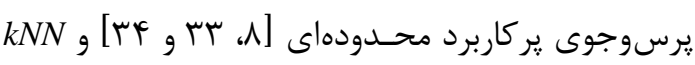

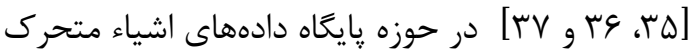
بـراى بررسـى انتخــاب شــند. نتــايج حاصـل از اعمـال

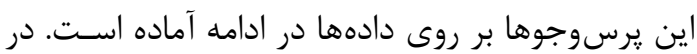

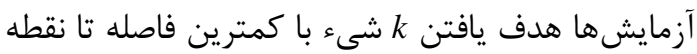
يرسوجوى مورد نظر در يك ليست غيـر مرتسب اسـت.

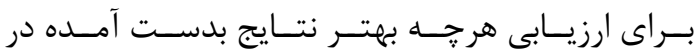

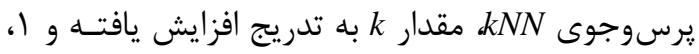

F-r - ارزيابى شاخص گذارى موقعيت جارى اشياء

متحر ك

تعـداد بــالاى بروزرســانىهـــاز از جملــهـ جـــالشهــاى شاخص گذارى موقعيت جارى اشياء متتحرى مـىباشـد. علاوه بر اين براى افزايش دقت نتايج يرسوجوهــا بايـد

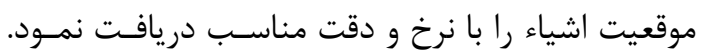
لذا روش كاهش داده در اين بخش تـاثير منفـى دارد و

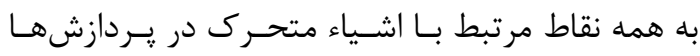
نياز است. اما انجام عمل تطبيق برنقشه برروى موقعيت

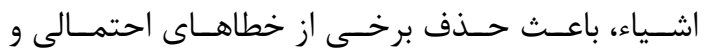

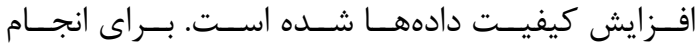
شاخص گذارى نقاط، ابتدا سگمنتهاى شبكه جادهاى با

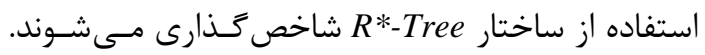
همانطور كه قبلاً عنوان شد ايسن سـاختار ثابـت بـوده و تغيير نمى كند. اطلاعات مربوط به موقعيت جارى اشياء

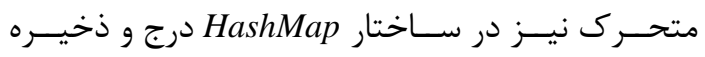
مـىشـود. همــه بروزرسـانىهــا در ايـن سـاختار انجـام مىشود. اشارهزرى دوطرفه بين اين ساختار و R*Tree وجود دارد كه مشخص مى كند شىء متحـــــ در كـدام

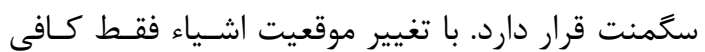
است اطلاعات مختصات شىء متحرك در ساختار مـورد

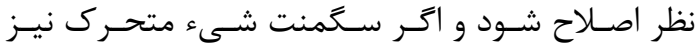
تغيير كرده بود، اشارهر مربوطه نيز بروزرسانى گردد. 
در نتايج حاصل كه در شكل (9) آمده اسـت، وقتى كــه

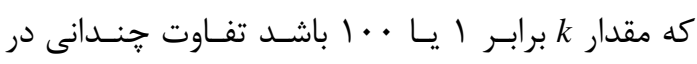
زمان اجراى يرسوجوى kNN ندارد، در واقع بيشـترين

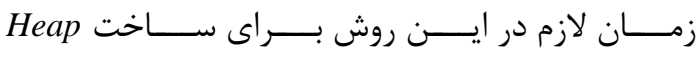

$$
\text { صرف مىشود. }
$$

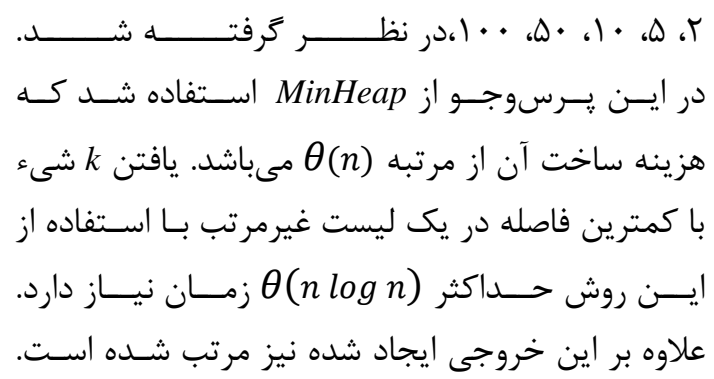

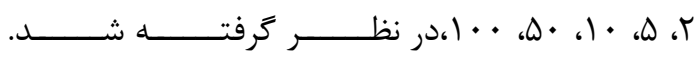

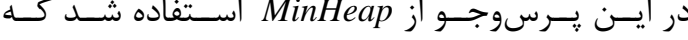
هزينه ساخت آن ار مرتبه (n)

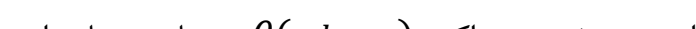
علاوه بر اين خروجى ايجاد شده نيز مرتب شـده اسـت.

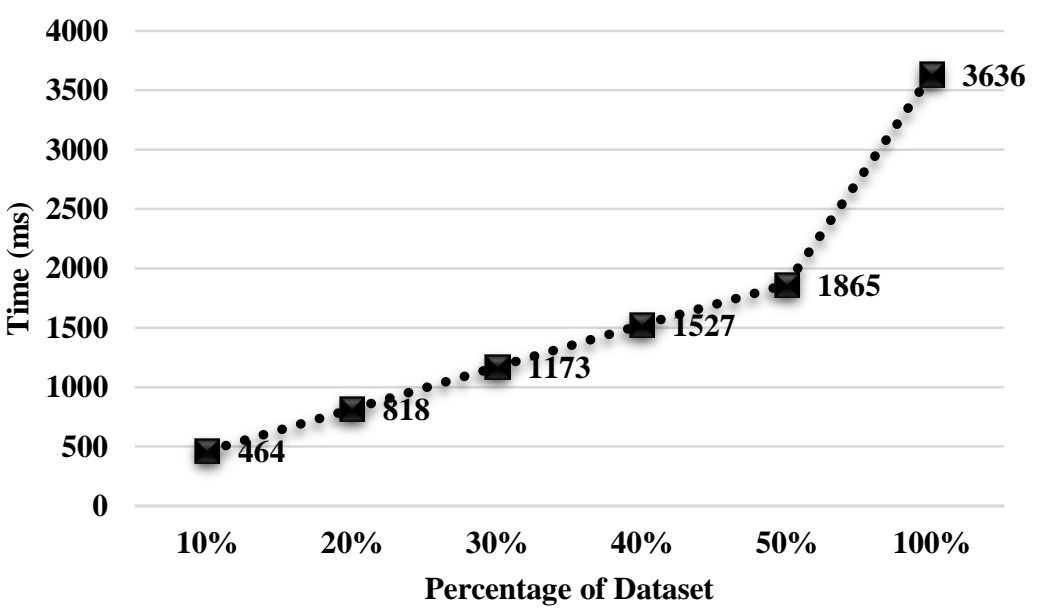

شكل ه: زمان ساخت شاخص براى درصدهاى مختلف مجموعه داده

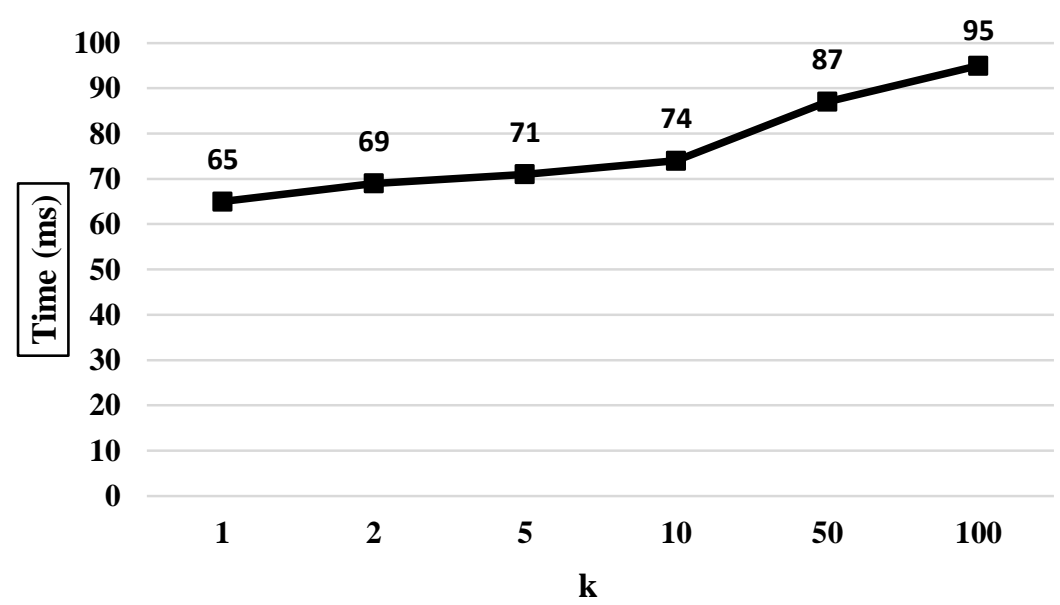

شكل 9: زمان اجراى يرسوجوى kNN براى kلهاى مختلف

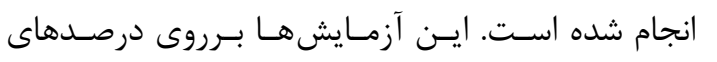
همجنين بهمنظور بررسى تأثير روش بيشنهادى بر روى

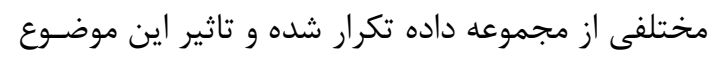

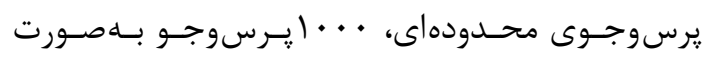

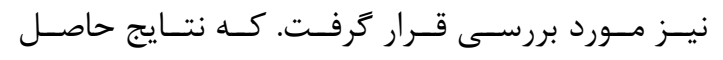

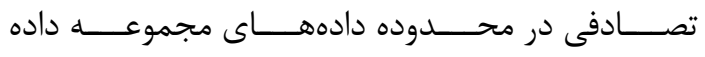
در شكل (V) آمده است.

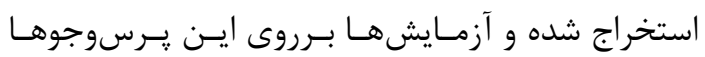




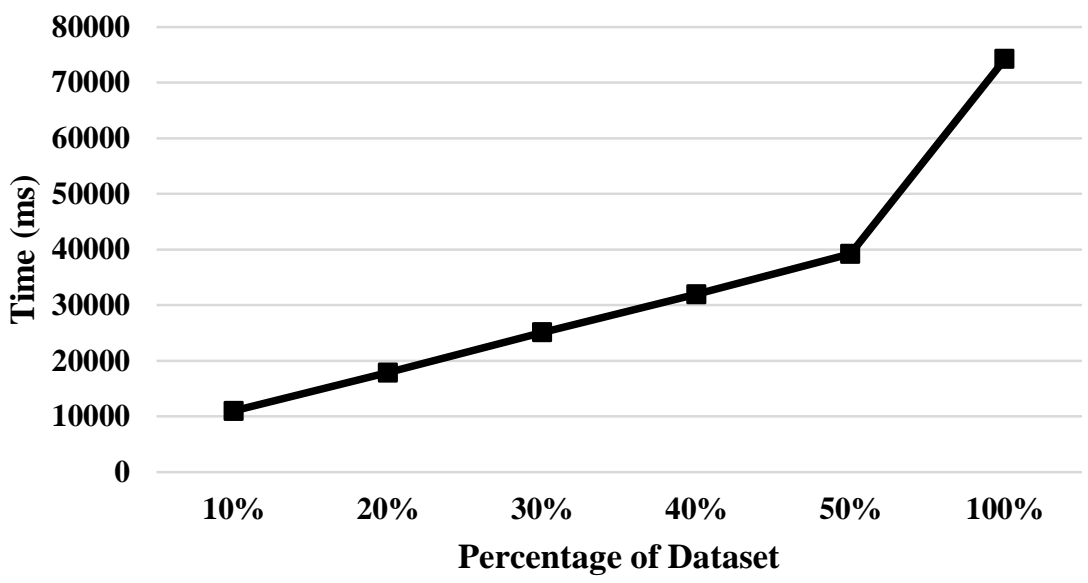

شكل マ: زمان انجام يرسوجوى محدودهاى

شــبكه جــادهاى، موقعيـت جــارى اشـــاء متحــــ و

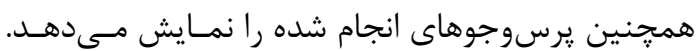
همانطور كه در اين شكل مشخص شده است، بيشترين حافظهاى مصرفى براى شاخص خذارى موقعيـت جـارى

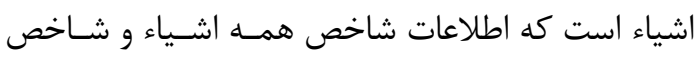
شبكه جادهاى در حافظه قرار مى گيرند.
ازآنجايى كه اين شـاخصهــا در حافظــه اصـلى ايجــاد و نتَهدارى مى شود علاوه بر زمان، ميزان حافظه مصـرفى آنى نيز داراى اهميت مى باشد. لذا بعد از اجراى هر مرحلـه،

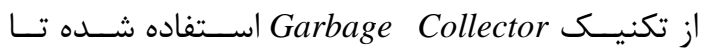
فضاى استفاده شده بهصورت دقيق محاسبه شود. شكل

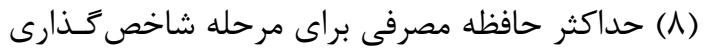

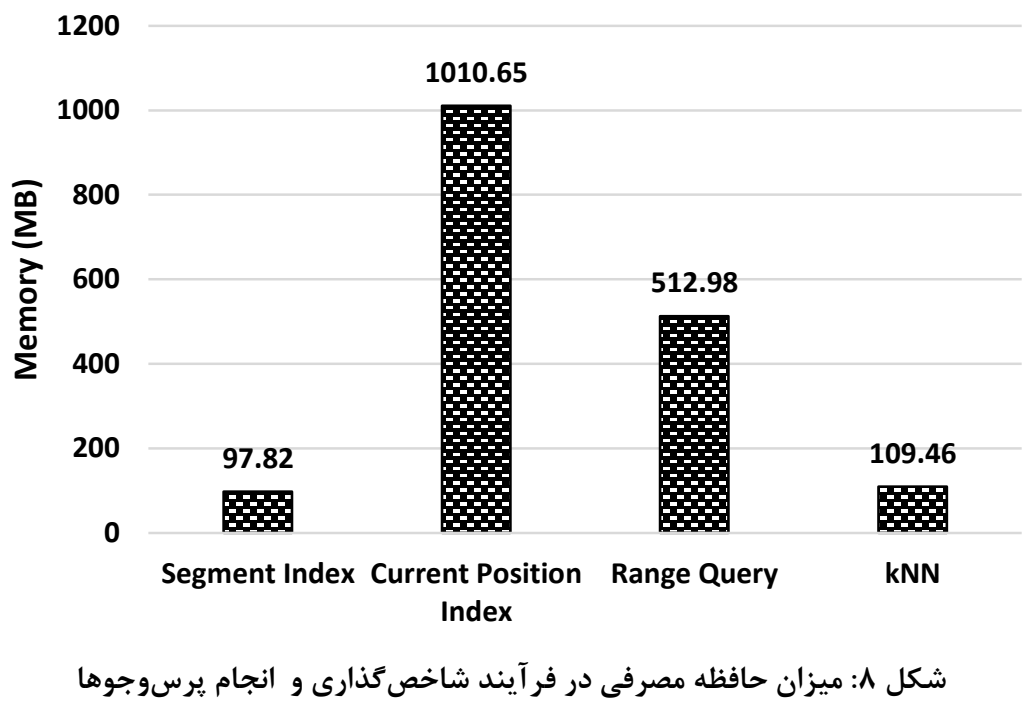

اين شاخص برروى ديسك ساخته و نكَهدارى مسىشـود

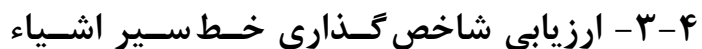
براى بهره بيشتر، در قسمت شاخصهاى زمانى :راكنده متحر ك

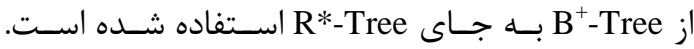

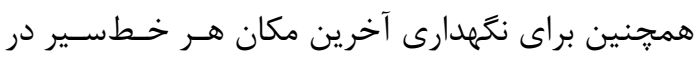

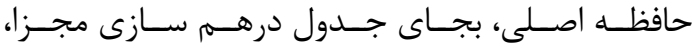

همان طور كه در بخش r.|.r اشاره شد، در روش PCPI براى شاخص گذارى دادهاى خطسير اشـياء متحــرى،

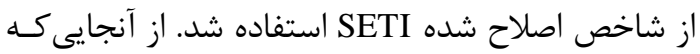


كاهش حجم داده برروى ديسك، بسيار قابل توجه است

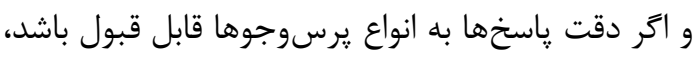

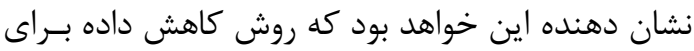
شاخص تذارى دادهها در برنامه هاى كاربردى، مناسب و وادي

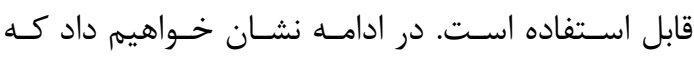

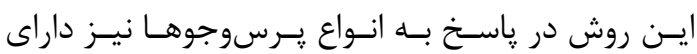
دقت قابل قبولى است. از نظر ميانكين زمانى براى ياسخ

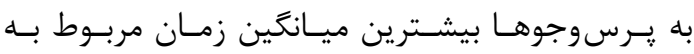
باركذارى شاخصهاى زمانى است و باركذارى صـفحات

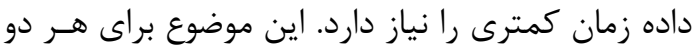

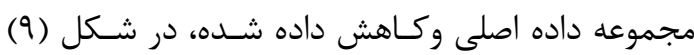

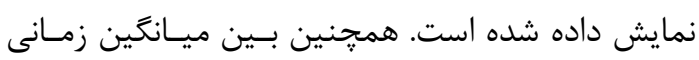

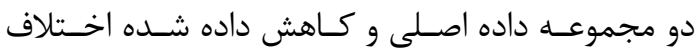

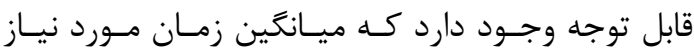

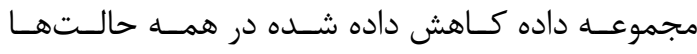

كمتر است.

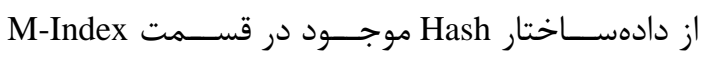

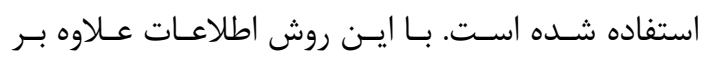
افزايش سرعت، امكان نكههدارى اطلاعـات بيشـترى نيـز

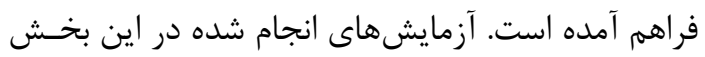
برروى هر دومجموعه داده اصـلى و كـاهش داده شـده،

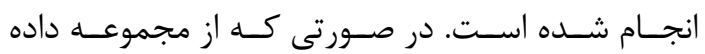

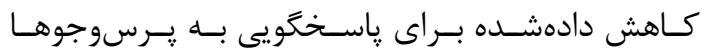

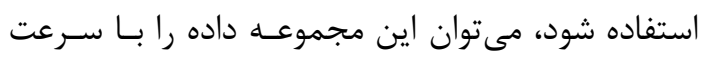

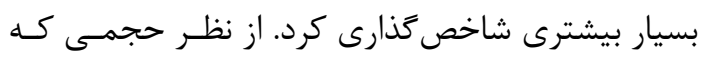

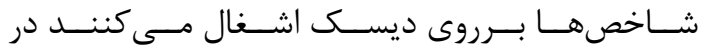

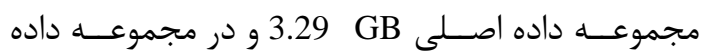

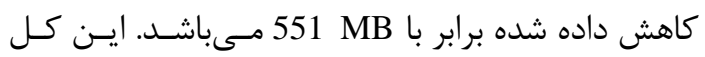
حجم شاخصهاى زمـانى و صـفحات دادهاى اسـت كـهـ برروى ديسك ذخيره شده است. البته بخش عمده ايـن

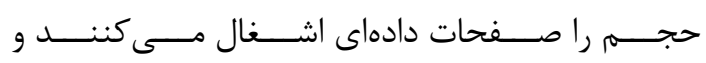
شاخصهاى زمانى حجم بسيار اندكى دارند. اين ميـزان

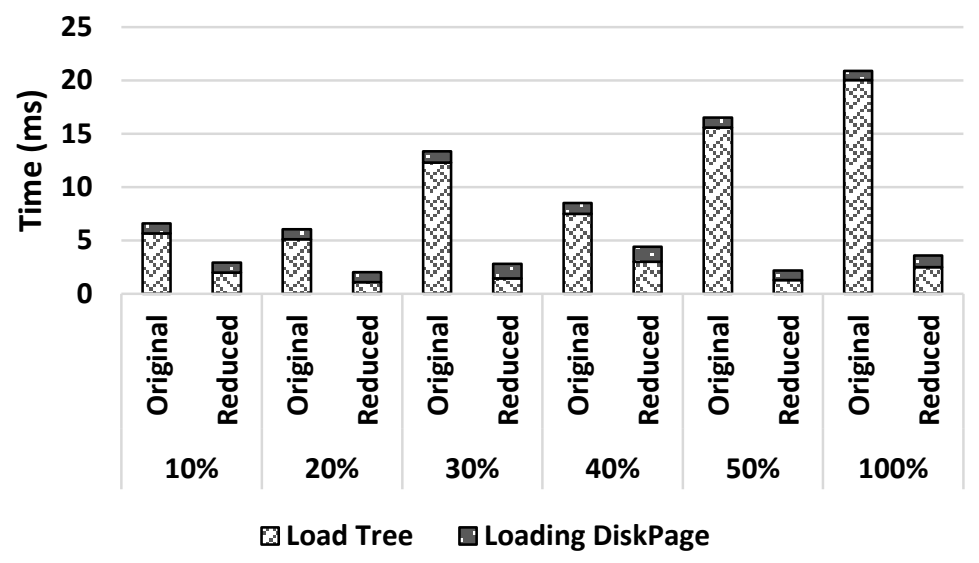

شكل 9: ميانكَين زمان بارَذارى صفحات داداى و شاخصهاى زمانى درصدهاى مختلف مجموعه داده اصلى و كاهش داده شده كاهش داده شده را نمايش مى دهد. همانطور كه در اين

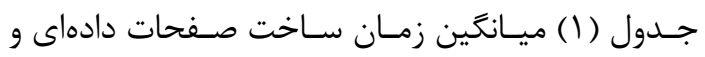

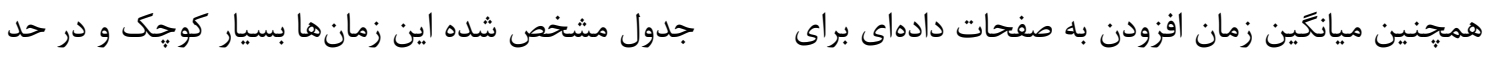

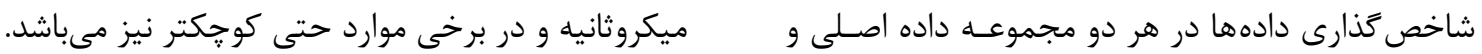




\begin{tabular}{|c|c|c|c|c|}
\hline \multicolumn{2}{|c|}{ ايجاد صفحات داده اي } & \multicolumn{2}{|c|}{ افزودن به صفحات داده اى } & \multirow[b]{2}{*}{ درصد مجموعه } \\
\hline اصلى & كاهش داده شده & اصلى & كاهش داده & \\
\hline 0.043677696 & 0.000120351 & 0.000120351 & 0.000963391 & $10 \%$ \\
\hline 0.043200126 & 0.000235849 & 0.000235849 & 0.000271481 & $20 \%$ \\
\hline 0.060285753 & 0.000791766 & 0.000791766 & 0.001173021 & $30 \%$ \\
\hline 0.055106195 & 0.000407914 & 0.000407914 & 0.000729927 & $40 \%$ \\
\hline 0.059595634 & $<0.0001$ & 0.000020351 & 0.000130582 & $50 \%$ \\
\hline 0.070595812 & $<0.0001$ & 0.000035849 & $<0.0001$ & $100 \%$ \\
\hline
\end{tabular}

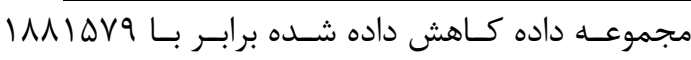
عمليات افزودن سگمنت مىباشد. همانطور كه در شكل دهو

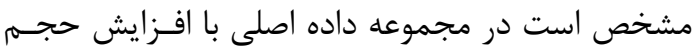
مجموعه داده زمان نيز افزايش يافته ولـى در مجموعـهـ داده كاهش داده شده زمان تغيير گ جندانى ندارد.
همجٍنين زمان افزودن سگمنتها در درصدهاى مختلف براى هر دو مجموعه داده اصلى و كـاهش داده شـده در شكل ( • () آمده است. لازم به ذكر است كه ايـن زمـان براى افزودن همه سخمنتها مسى باشـد. ايـن تعـداد در

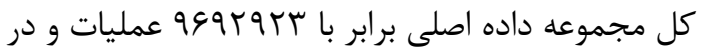

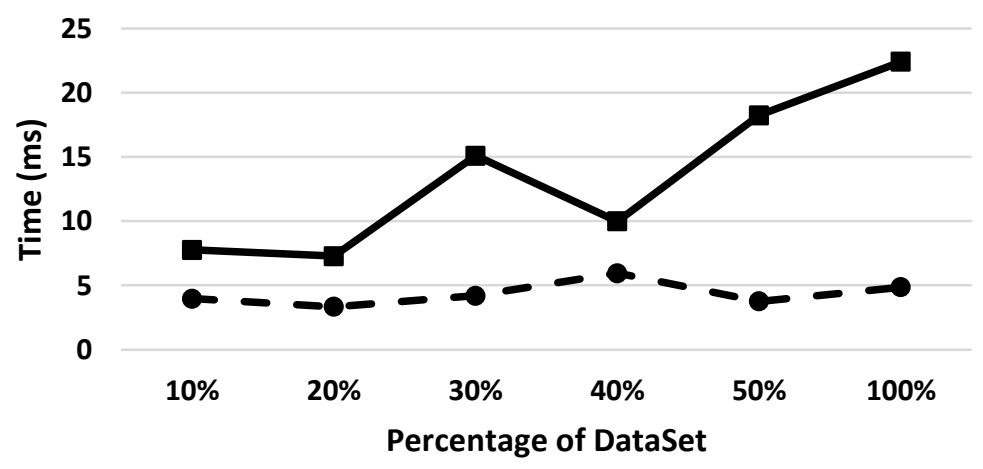

شكل •ا: ميانگين زمان افزودن سگمنتها به صفحات دادهاى براى شاخص حذارى درصدهاى مختلف مجموعه داده

فوق بهجز فاصله زمانى برروى درصدهاى مختلفى از هر

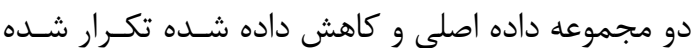
است كه در ادامه به بررسى نتايج آن خواهيم يرداخت.

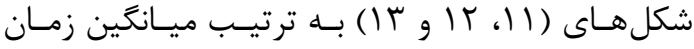

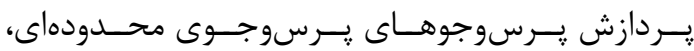

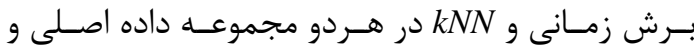
كاهش داده شده و براى درصدهاى مختلـف مسىباشــــ

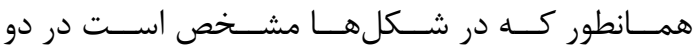
يرسوجوى محدودهاى و kNN با افزايش حجم مجموعه

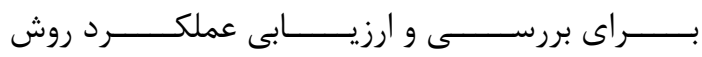

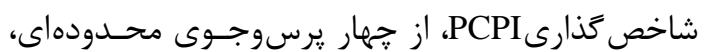

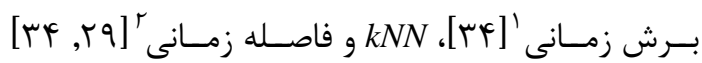

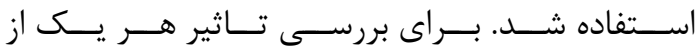

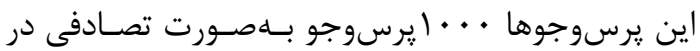

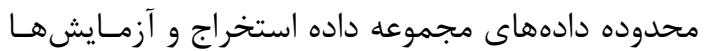

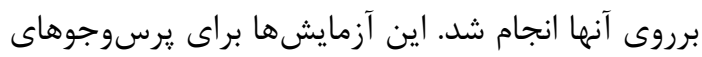

\footnotetext{
${ }^{1}$ Time-Slice query

${ }^{2}$ Time Interval Query
} 
حجم مجموعه دادهها، نسبت افزايش زمان يردازش هـر

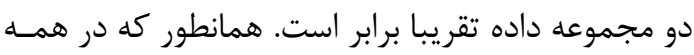

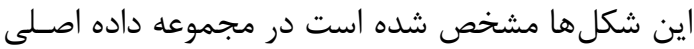
با افزايش حجم مجموعه داده زمان نسبت بــه مجموعـهـ داده كاهش داده شده افزايش بيشترى داشته است.
داده زمان يردازش در مجموعـهـ داده اصـلى نسـبت بــهـ

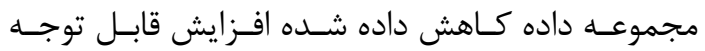
خواهد داشت. اما در يرسوجوى بـرش زمـانى بــه طـور

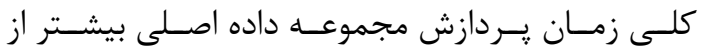
مجموعه داده كاهش داده شده اسـت. ولى بــا افـزايش

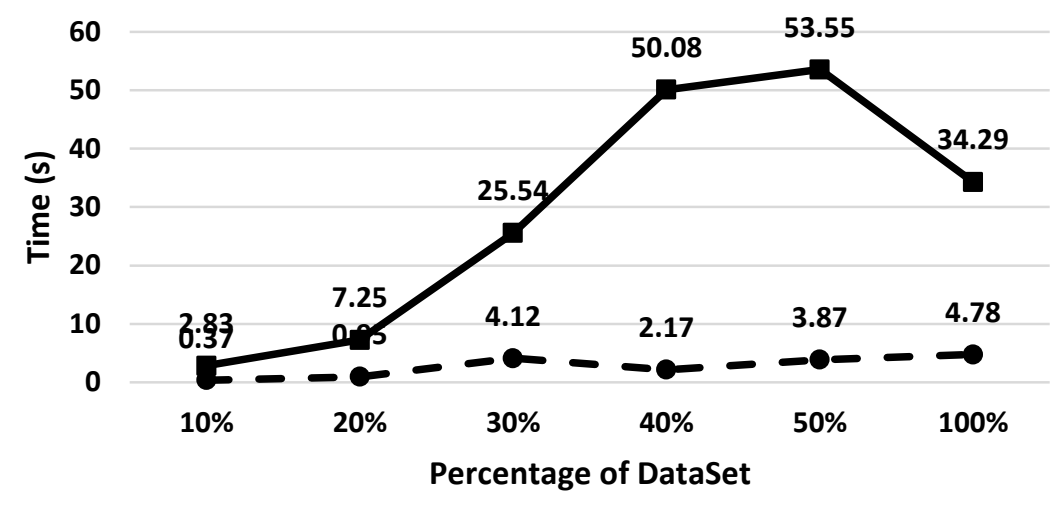

$\longrightarrow$ Original $-\infty$ Reduced

شكل ||: ميانكَين زمان بردازش يرسوجوى محدودهاى

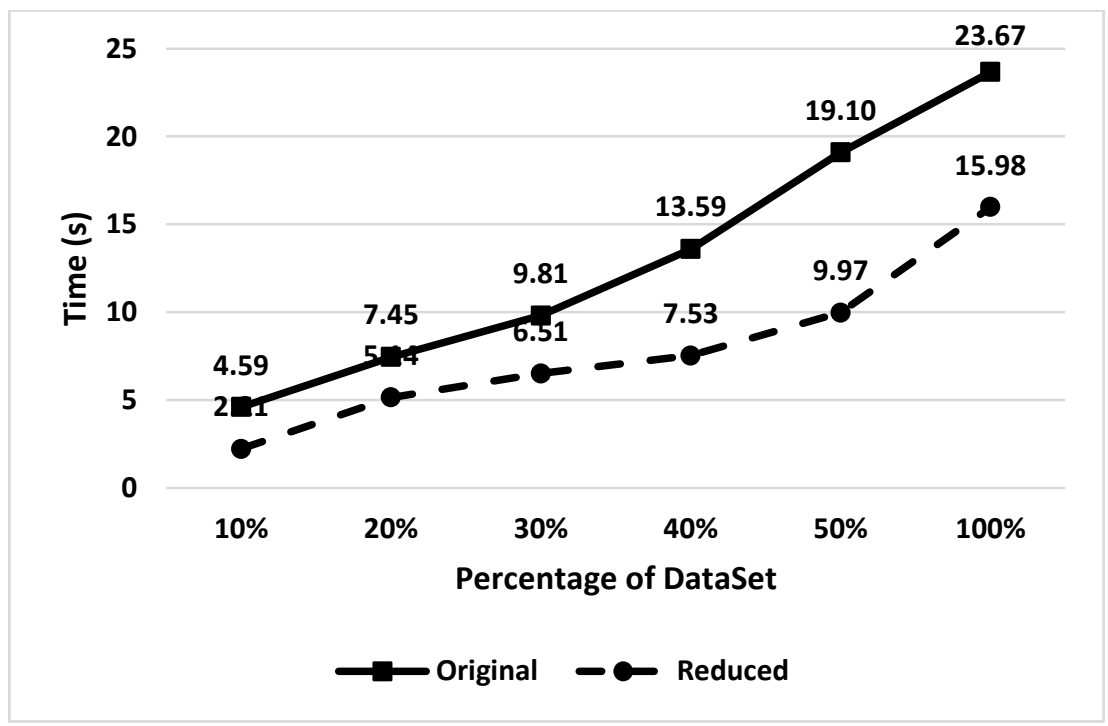

شكل rا: ميانكَين زمان بردازش برسوجوى برش زمانى 


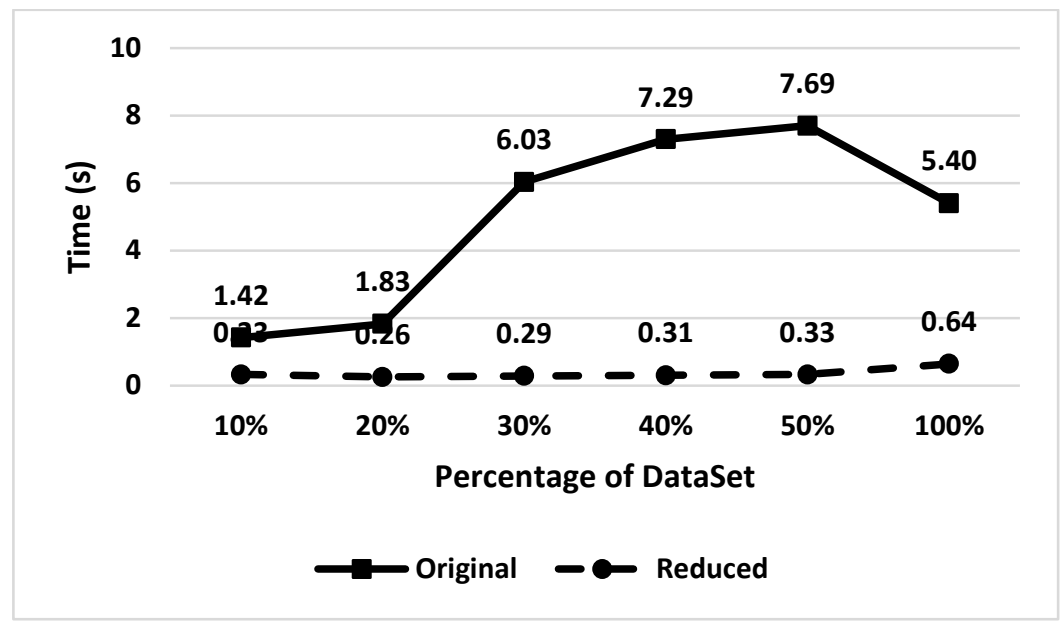

شNN شكل با: ميانگين زمان يردازش يرس وجوى

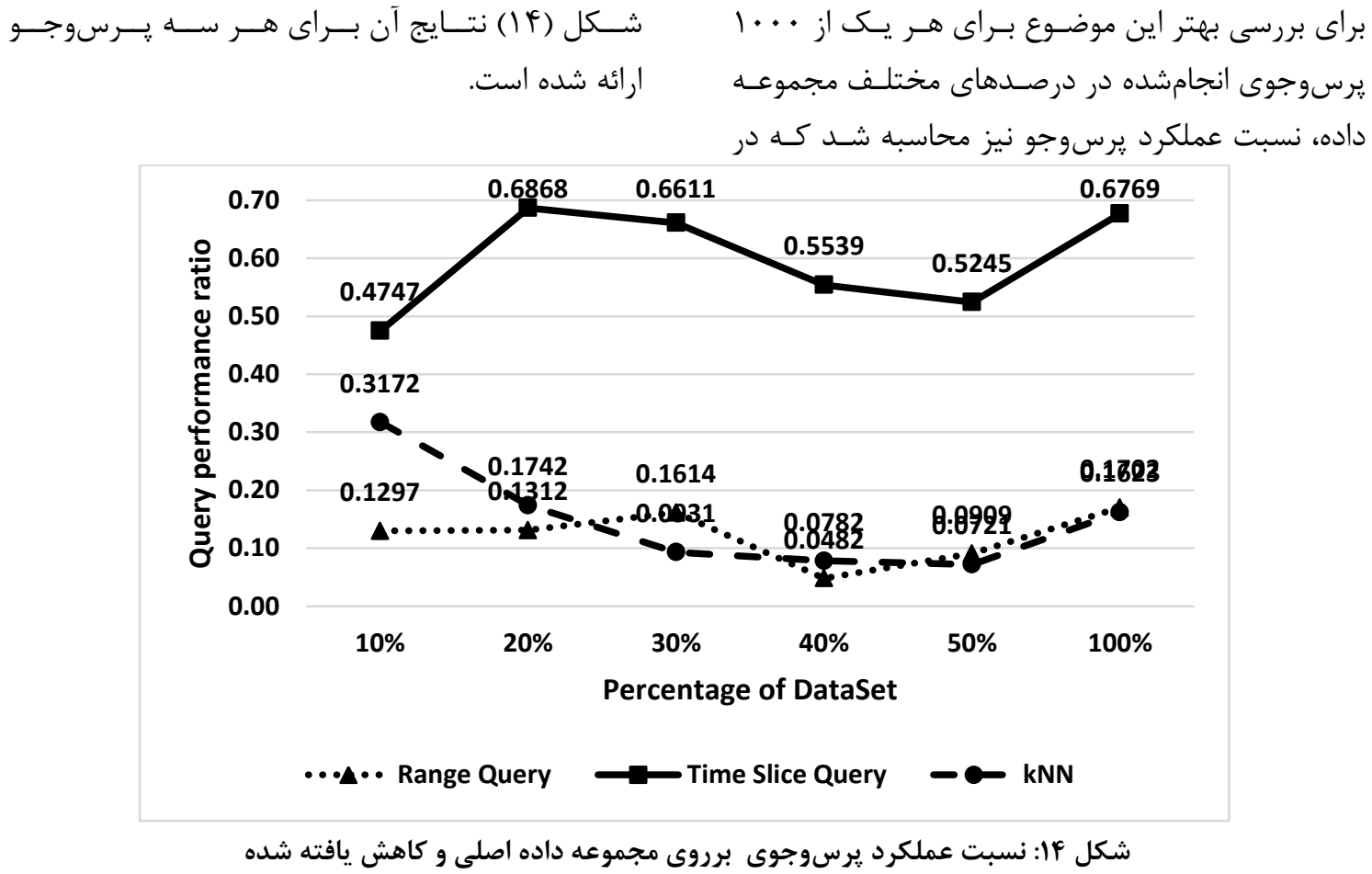

آمده است. همجنــين دقـت ياســخ ايسن يـرس وجـو در مجموعه داده كاهش داده شده نسبت به مجموعـه داده

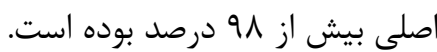

اما براى يرسوجوى فاصله زمانى بـراى دريافت ڤياســخ

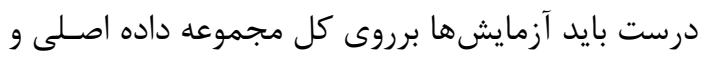
كاهش داده شده انجام مىشد. در نتيجه ميانگين زمـان

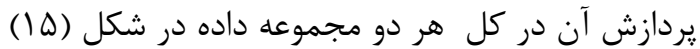




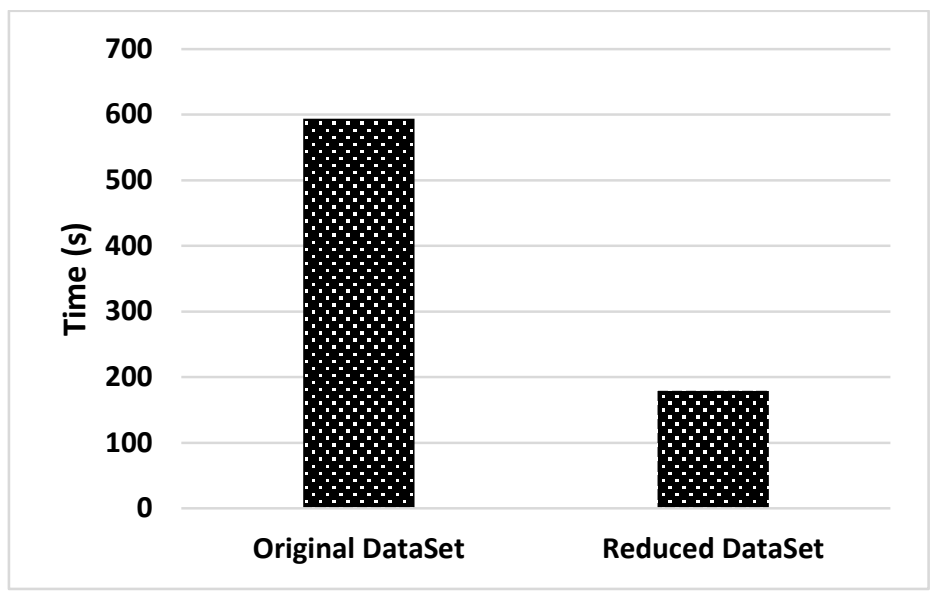

شكل ها: ميانغَين زمان پيردازش برس وجوى فاصله زمانى

واقعى دقت افزايش خواهد يافت. همجنـين دليـل ديخـر كاهش دقت در هر سه يرس وجو خطاهايى هستند كـــ دهـ حتى بعد از مرحله يِيش يردازش هنوز در مجموعه ده داده

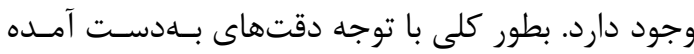

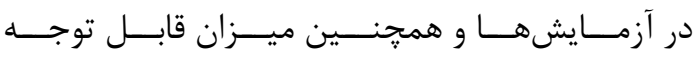

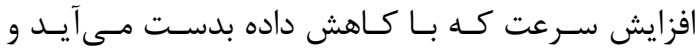

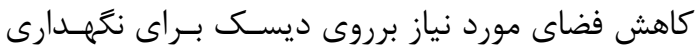

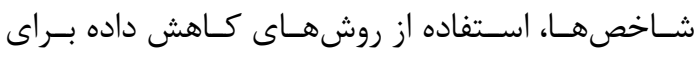

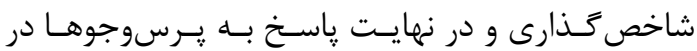
بيشتر كاربردها و سرويسهاى LBS/ITS مناسب بـوده

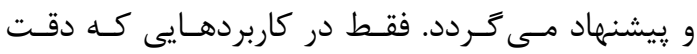

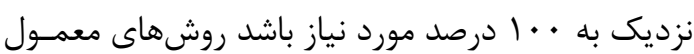
كاهش داده مفيد نخواهد بود.
همجنــين شـكل (ع) (1) نمــودار ميــانگين دقـت ايسـن يرسوجوها براى درصدهاى مختلف را نشـان مسىدهـد.

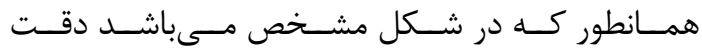
يرسوجوى برش زمانى در درصدهاى مختلـف بـيش از

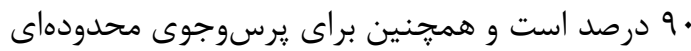

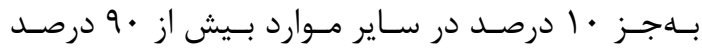

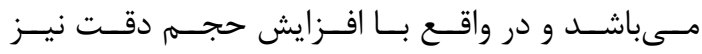
افزايش مى يابد. فقط در يرس و جــوى kNN در بيشـتر

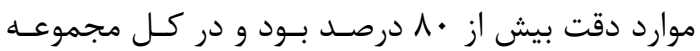
داده نيز هنوز بيش از • V درصد بوده كــهـ بـا توجـهـ بــهـ ميزان كاهش انجام شده دقت قابل قبولى اسـت.. دليـل

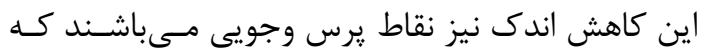
بهصورت تصادفى انتخاب شده است و با انتخــاب نقـاط

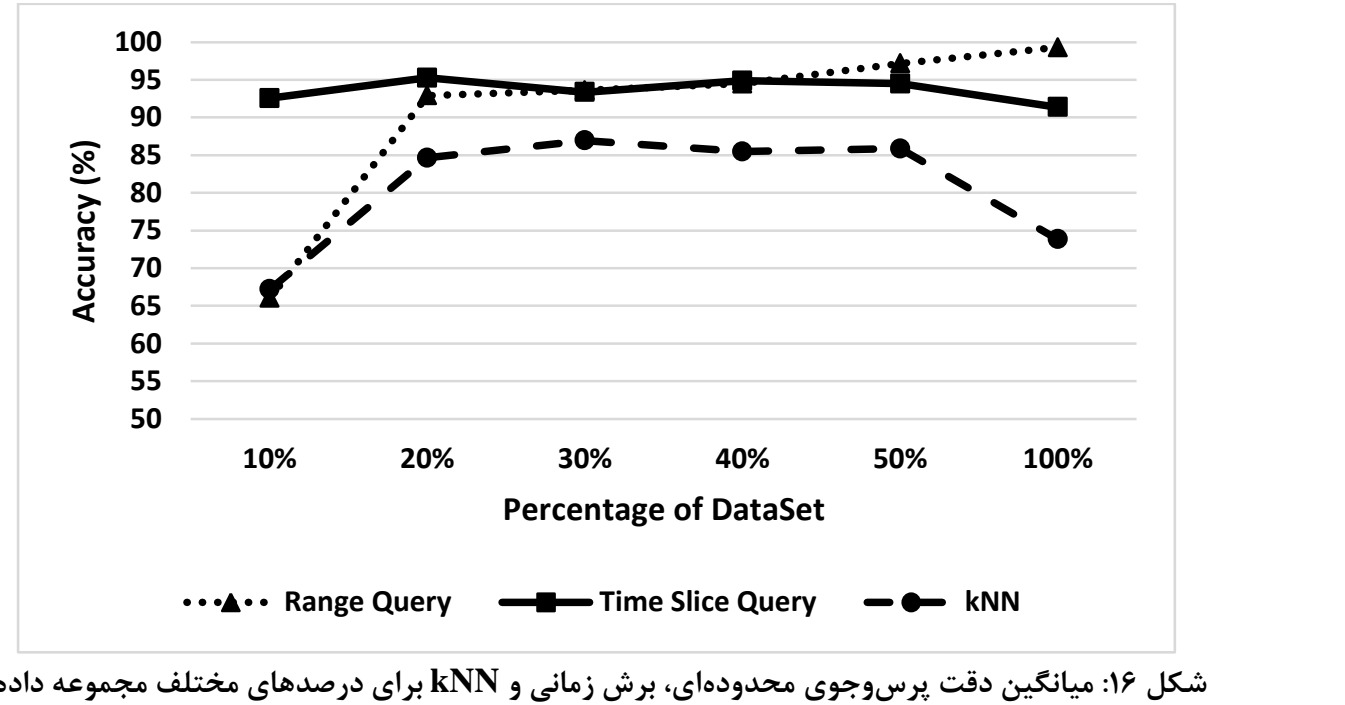


دادهــاى هـــــــــلول در داخـل صـفحات دادهاى مجـزا بهصورت سگمنت ذخيره شده است. همجنين براى هـر

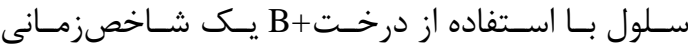
يراكنده ايجادشده كه به دادههاى آن سلول اشـاره دارد.

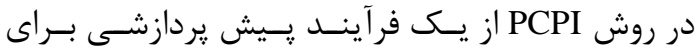
افزايش كيفيت و دقت شاخصها و يرسوجوها اسـتفاده شده است. در ايـن روش بــا اسـتفاده از الكَــوريتمهــاى

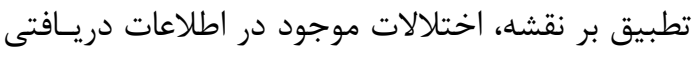
از اشياء متحرك، حذف مىشـوند. در ايـن مقالـه تـاثير

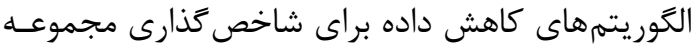

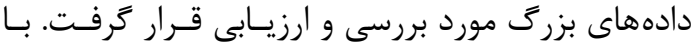

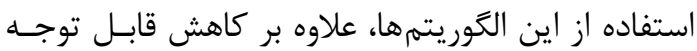

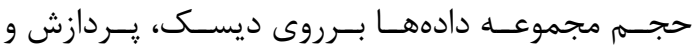

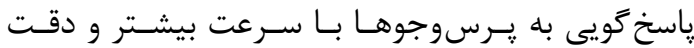

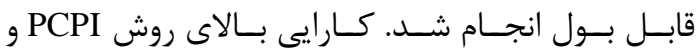

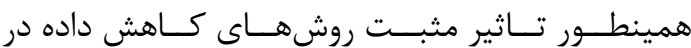
آزمايشهاى مختلف بـر روىى دو مجموعـهـ داده اصسلى و كاهش داده شده، نشان داده شد.

[1] C.-I. Cha, S.-W. Kim, J.-I. Won, J. Lee, and D.-H. Bae, "Efficient Indexing in Trajectory Databases.," International Journal of Database Theory and Application, vol. 1, pp. 21-28, 2008.

[2] C. Lv, Y. Xu, J. Song, and P. Lv, "A data frame based spatiotemporal indexing algorithm for moving objects," presented at the 12th World Congress on Intelligent Control and Automation (WCICA), Guilin, China, 2016.

[3] Y. Shi, J. Feng, Z. Ren, and W. Xie, "Hadoop-based Probabilistic Range Queries of Moving Objects on Road Network," 2016.

[4] Y. Zheng and X. Zhou. (2011). Computing with Spatial Trajectories [Online].

[5] C. Parent, S. Spaccapietra, C. Renso, G. Andrienko, N. Andrienko, V. Bogorny, et

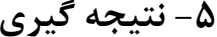

با توجه به حجم بالاى دادههاى مكـانى -زمـانى و تنـوع بالاى سيستمهاى هوشمند حمل و نقل و سرويسهـاى

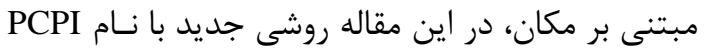
براى شاخص كذارى دادههاى خطسير اشياء متحرك در دو زمان كذشته و حال بلصصورت همزمان ارائـه شـد. در

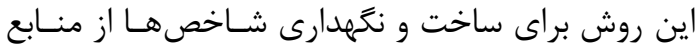
يردازشى يكيار جه استفاده مىشـود. در ايـن روش از دو دو داده ساختار براى شاخص كذارى اسـتفاده شـده اسـتـ يك داده ساختار در حافظه اصلى وظيفه شاخص كذارى

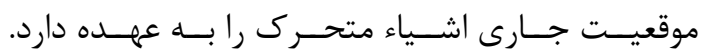
اين دادهاختار، داراى دو بخش ايستا و يويا اسـت كـهـ هدف آن حداكثر كردن بخش ايسـتا وكمينـه سـاختن بخش يويا براى بهينه سازى تعداد بروزرسانىهـا اسـت.

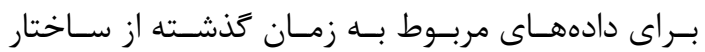

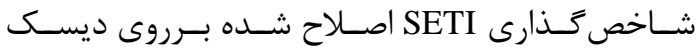
استفاده شد. در اين داده ساختار بعد مكان و زمان جـدا تـا

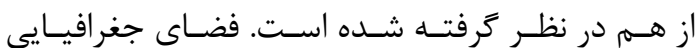
موجود به كمك سلولهاى شش ضلعى تقسـيم شـده و

al., "Semantic trajectories modeling and analysis," ACM Computing Surveys (CSUR), vol. 45, pp. 1-32, 2013.

[6] C. Renso, S. Spaccapietra, and E. Zimányi, Mobility data: modeling management and understanding: Cambridge University Press, 2013.

[7] V. P. Chakka, A. C. Everspaugh, and J. M. Patel, "Indexing Large Trajectory Data SetsWith SETI," in CIDR 2003.

[8] Y. Fang, J. Cao, Y. Peng, N. Chen, and L. Liu, "Indexing the Past, Present and Future Positions of Moving Objects on Fixed Networks," presented at the International Conference on Computer Science and Software Engineering, Wuhan, Hubei, 2008.

[9] M. Pelanis, S. Šaltenis, and C. S. Jensen, "Indexing the past, present, and anticipated future positions of moving objects," ACM 
Transactions on Database Systems (TODS), vol. 31, pp. 255-298 March 2006.

[10]D. Lin, C. S. Jensen, B. C. Ooi, and S. Šaltenis, "Efficient indexing of the historical, present, and future positions of moving objects," in Proceedings of the 6th international conference on Mobile data management, ACM, New York, NY, USA, 2005, pp. 59-66.

[11] K.-S. Kim, S.-W. Kim, T.-W. Kim, and K.-J. $\mathrm{Li}$, "Fast indexing and updating method for moving objects on road networks," in Proceedings of the Fourth international conference on Web information systems engineering workshops(WISEW'03), Rome, Italy, 2003, pp. 34-42.

[12] M. Hashemi and H. A. Karimi, "A weightbased map-matching algorithm for vehicle navigation in complex urban networks," Journal of Intelligent Transportation Systems, pp. 1-18, 17 March 2016.

[13] M. Bierlaire, J. Chen, and J. Newman, "A probabilistic map matching method for smartphone GPS data," Transportation Research Part C: Emerging Technologies, vol. 26, pp. 78-98, January 2013.

[14]P. Newson and J. Krumm, "Hidden Markov map matching through noise and sparseness," in 17th ACM SIGSPATIAL International Conference on Advances in Geographic Information Systems, Seattle, Washington, 2009, pp. 336-343.

[15]I. S. Popa, K. Zeitouni, V. Oria, and A. Kharrat, "Spatio-temporal compression of trajectories in road networks," GeoInformatica, vol. 19, pp. 117-145, January 2015.

[16]R. Song, W. Sun, B. Zheng, and Y. Zheng, "PRESS: A Novel Framework of Trajectory Compression in Road Networks," Proceedings of the VLDB Endowment, vol. 7, pp. 661-672, May 20142014.

[17]G. Kellaris, N. Pelekis, and Y. Theodoridis, "Map-matched trajectory compression," Journal of Systems and Software, vol. 86, pp. 1566-1579, June 2013.
[18] M. F. Mokbel, T. M. Ghanem, and W. G. Aref, "Spatio-Temporal Access Methods," IEEE Data Engineering Bulletin, vol. 26, pp. 40-49, 2003.

[19] L.-V. Nguyen-Dinh, W. G. Aref, and M. F. Mokbel, "Spatio-Temporal Access Methods: Part 2 (2003 - 2010)," IEEE Data Engineering Bulletin, vol. 33, pp. 46-55 2010.

[20] Y. Manolopoulos, A. Nanopoulos, A. N. Papadopoulos, and Y. Theodoridis. (2005, November 21). R-Trees: Theory and Applications (2006 ed.) [Online].

[21] Y. Tao and D. Papadias, "MV3R-Tree: A Spatio-Temporal Access Method for Timestamp and Interval Queries," in Proceedings of the 27th International Conference on Very Large Data Bases (VLDB '01), Roma, Italy, 2001, pp. 431440.

[22] M. A. Nascimento, J. R. O. Silva, and Y. Theodoridis, "Evaluation of Access Structures for Discretely Moving Points," in Proceedings of the International Workshop on Spatio-Temporal Database Management (STDBM'99), 1999, pp. 171-188.

[23] D. Pfoser, C. S. Jensen, and Y. Theodoridis, "Novel Approaches to the Indexing of Moving Object Trajectories," in Proceedings of the 26th International Conference on Very Large Data Bases (VLDB '00), Cairo, Egypt, 2000, pp. 395-406.

[24] C.-I. Cha, S.-W. Kim, J.-I. Won, J. Lee, and D.-H. Bae, "Efficient Indexing in Trajectory Databases," International Journal of Database Theory and Application, vol. 1, pp. 21-28, 2008.

[25] X. Xiong, M. F. Mokbel, and W. G. Aref, "LUGrid: Update-tolerant Grid-based Indexing for Moving Objects," in the 7th International Conference on Mobile Data Management (MDM '06), Nara, Japan, 2006, p. 13.

[26] Y. N. Silva, X. Xiong, and W. G. Aref, "The RUM-tree: supporting frequent updates in R-trees using memos," The VLDB Journal 
- The International Journal on Very Large Data Bases, vol. 18, pp. 719-738 June 2009 2009.

[27]Z. Song and N. Roussopoulos, "SEB-tree: An Approach to Index Continuously Moving Objects," in MDM '03 Proceedings of the 4th International Conference on Mobile Data Management, Melbourne, Australia, 2003, pp. 340-344.

[28] Y. Tao, D. Papadias, and J. Sun, "The TPR*-Tree: An Optimized Spatio-temporal Access Method for Predictive Queries," in VLDB '03 Proceedings of the 29th international conference on Very large data bases, 2003, pp. 790-801.

[29]Z.-H. Liu, X.-L. Liu, J.-W. Ge, and H.-Y. Bae, "Indexing Large Moving Objects from Past to Future with PCFI+-Index," in Proceedings of the Eleventh International Conference on Management of Data(COMAD 2005), Goa, India, 2005, pp. 131-137.

[30]H. Ferhatosmanoğlu, D. Agrawal, Ö. Eğecioğlu, and A. El Abbadi, "Optimal Data-Space Partitioning of Spatial Data for Parallel I/O," Distributed and Parallel Databases vol. 17, pp. 75-101, January 2005.

[31] M. R. Abbasifard, H. Naderi, Z. Fallahnejad, and O. Isfahani Alamdari, "Approximate aggregate nearest neighbor search on moving objects trajectories," Journal of Central South University, vol. 22, pp. $4246-$
4253, 08 November 20152015.

[32]R. Sedgewick and K. Wayne, Algorithms, 4 ed.: Pearson Education, 2011.

[33]H. Cao, O. Wolfson, and G. Trajcevski, "Spatio-temporal data reduction with deterministic error bounds," The VLDB Journal-The International Journal on Very Large Data Bases, vol. 15, pp. 211-228 September 2006.

[34]Z. Song and N. Roussopoulos, "SEB-tree: An Approach to Index Continuously Moving Objects," presented at the Proceedings of the 4th International Conference on Mobile Data Management, 2003.

[35]M. R. Abbasifard, B. Ghahremani, and H. Naderi, "A Survey on Nearest Neighbor Search Methods," International Journal of Computer Applications, vol. 95, pp. 39-52, June 20142014.

[36] N. Bhatia and V. Ashev, "Survey of Nearest Neighbor Techniques," International Journal of Computer Science and Information Security, vol. 8, pp. 1-4, 2010.

[37]S. Dhanabal and S. Chandramathi, "A Review of various k-Nearest Neighbor Query Processing Techniques," Computer Applications, vol. 31, pp. 14-22, 2011. 


\title{
Indexing the past and current position of moving objects in large- scale dataset
}

\author{
Abbasifard, M.R. ${ }^{1}$, Naderi, H. ${ }^{2 *}$ \\ 1- Ph.D. Candidate of Software Engineering, Iran University of Science and Technology, Tehran, Iran \\ 2- Assistant professor in School of Computer Engineering, Iran University of Science and Technology, Tehran, Iran
}

\begin{abstract}
By increasing intelligent transportation systems (ITS) and location based services (LBS) that take advantage of spatiotemporal data, these data have increased the necessity for new indexing techniques. Indexing methods index these data generally in the past, present or future. Creating an integrated index for indexing data and also answering to various queries which can reduce indices' updating time, is one of the challenges. The current study introduces an integrated method called "PCPI" (Past and Current Position Indexing) to index and store spatio-temporal data of the past and present in a simultaneous manner in the disk and main memory respectively that has ability to answer various spatio-temporal queries. PCPI uses a same resources for processing and creating indices in two different times. In this method, two data structure is used integratedly: the first data structure indexes and stores current position of moving objects in the main memory, and the second data structure on disk for trajectory data of moving objects that have high volume and cannot be stored in main memory. In addition, PCPI uses map matching methods to remove noises - e.g. stationary state noises- in the data received from the moving objects; this feature adds to accuracy and reliability of the query results. Effects of data reduction techniques on accelerating indexing and query processing and reducing disk space consumption (in massive datasets) were examined. Results of the comparisons made based on the experiments showed higher efficiency of the indexing structure.
\end{abstract}

Key words: Moving Objects Databases, Trajectory Indexing, Spatio-Temporal Data, Query Processing.

Correspondence Address. Moving Objects Database (MODB) Lab., School of Computer Engineering, Iran University of Science and Technology, Tehran 1684613114

Tel: $+98-21-73225353$

Email: naderi@iust.ac.ir 